USAD, Bahar 2021; (14 ): 105-136

E-ISSN: 2548-0154

\title{
KİTÂBU BAĞDÂD’IN TARİHİ DEĞERİ
}

\section{THE HISTORICAL VALUE OF KITABU BAGHDAD}

Mustafa HIZMETLI *

$\ddot{O} z$

İslam tarihçiliği içerisinde şehir ve bölge tarihlerinin ortaya çıkışı Hasan-ı Basrî'nin Fezâilü Mekke'yi yazmasıyla başlamıştır. 9. Yüzyılda yazılan şehir tarihleri arasında İbn Tayfur'un Kitâbu Bă̆dad'ının ayrı bir yeri vardır. Bu makalede eserin tarihi değerini ortaya koymayı hedefledik. Ilkin yazarın kökeni, hayatı, eğitimi, mesleği, hocaları ve öğrencileri ile kişiliği hakkında bilgi verilmiş, önemli eserlerinden söz edilmiştir. Eserin günümüze ulaşan altınc cildini ilk kez British Museum'daki yazma nüshasın esas alarak 1908'de yayınlayan Hans Keller'den itibaren çeşitli baskıları yapılan kitabın elimizdeki nüshası ve baskıları tanıtılmıştır. Me'mun döneminde doğup yetişen müellif, sonraki sekiz halife dönemini idrak ettikten sonra 893'te ölmüştür. Müellifin eserini

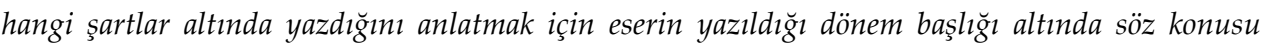
dönemdeki başlıca siyasi olaylar hakkında kısa bilgi verilmiştir. Aynı zamanda müellifin çağında yetişen önemli müellifler ve eserler hakkında bilgi verilerek eserin nasıl bir kültürel ortamın mahsulü olduğu ortaya konmaya çalışılmıştır. Müellifin metodu ve kaynaklar başlı̆̆ı altında önce İbn Tayfur'un tarihçiliğinde olaylar kronolojik sırayla anlatan çağdaşlarından farklılaşan metoduna vurgu yapılmıştır. Müellif her halifenin dönemini müstakil olarak değerlendirmiş, dönemin siyasi olaylarını, atanan görevlileri ve halifeyle ilişkilerini ele aldıktan sonra ilim, edebiyat, şarkı ve eğlence meclislerinden söz etmiştir. Kullandığ yöntemin farklılı̆̆ı, üslubunun sade ve ağırbaşlılı̆̆ı ona

\footnotetext{
*Prof. Dr., Bartın Üniversitesi Edebiyat Fakültesi Tarih Bölümü, Bartın/Türkiye, mhizmetli@bartin.edu.tr,
} https://orcid.org/0000-0002-3924-7081 
çă̆daşları arasında ayrı bir yer kazandırmıştır. İbn Tayfur, Bağdat ve Irak'ın tarihini ilk yazan bağımsız bir tarihçidir. Bunu eserinin ve planının özgünlüğünden anlıyoruz. Kaynaklarının çoğu şifahidir. Çünkü henüz yazll tarih eserlerinin yeni ortaya çıktı̆̆ı bir dönemde eserini yazmıştır. Eserini yazarken kendi şahsi gözlemlerinin yan sıra çağdaşı ravilerin aktarımlarından da yararlanmıştır. Ravileri arasında yüksek bürokratların kâtiplerinin yanı sıra, halifenin sarayındaki nedimler, gece sohbetlerindeki arkadaşlar ve bunlarm haberlerini merakla izleyen ileri gelenler bulunmaktaydı. Aktardığ $ı$ haber ve bilgilerin ravilerin darülhilafedeki siyasi, sosyal ve mesleki konumlarıla ilgili olduğunu görüyoruz. Bu da müellifin rivayetleri doğrulama ve seçme konusundaki titizliğinin bir göstergesidir. Tahiroğulları gibi önemli ailelerin haberlerini onlara yakm kişilerden aktarmasını buna örnek verebiliriz. Müellif meşhur şarkıcıların anlatımlarıyla dönemin eğlence hayatımı yansıtırken, aktardığı 500 beyitle Arap şiiri konusundaki bilgisini ortaya koymuştur. Tarihçilerin kaynak olarak Kitabu Bağdad'dan ne ölçüde yararlandıklarının da ortaya konduğu çalışmada müellifin ravi listesi ek olarak verilmiştir.

\title{
Anahtar Kelimeler
}

İbn Tayfur, Kitabu Bă̆gad, Şehir Tarihi, Me'mun, Tahiroğulları

\begin{abstract}
Within the history of Islam emergence of city and regional histories begins with Fezailü Mekke written by Hasan-ı Basri. Among the city histories written in 9th century A.C. Ibn Tayfur's Kitabu Baghdad has its own place. In this article our aim is to highlight the historical value of this given book. First of all, information about the writer's origins, life, educational background, occupation, tutors and students, as well as information about his important works, has been given. Presentation of the copy and various prints of the book we have-beginning from the book including six chapters that came to our day published by Hans Keller in 1908 based on the manuscript copy of the book in British museum-is also made in this article. The writer, who was born and raised during the period of Me'mun, died in 893 A.C. after witnessing the following eight caliph after Me'mun. So as to make the circumstances under which this book was written by the author better comprehended brief information about the political events of this period is also given under the title of era that the book was written in. Also, information about contemporary writers and their products of the given period is presented for indicating what kind of a cultural context this book is a product of. Under the title of writer's method and references, authentic features of Ibn Tayfur's history that differ from his contemporary historians who only made a chronological alignment of events is stressed on. The writer evaluated the period of each caliph independently; following assessment of political events, appointed authorities and their relation with the Caliph he tells about contexts related with science, lecture, music and entertainment in the related era. His original methods and the simplicity, as well as a refined touch, in his style gives the writer a distinctive place amongst contemporary historians of his age. Ibn Tayfur is the first independent historian who wrote about history of Baghdad and Iraq which
\end{abstract}


can well be understood from the originality of his book and plan. A considerable portion of his sources are verbal since he was writing in a period in which historical sources in a written format were just emerging. He benefited also of transfers from his contemporary informants as well as his own observations. Among his informants there were secretaries of high ranking bureaucrats, courtiers in the caliph's palace, his mates in evening talks and leading figures of the society following news from these sources with curiosity. News and information supplied by him seem to be closely related to the political, social and occupational positions of his informants in the caliphate capital (Darulhilafe), which indicates his precision and rigor about verifying and filtering the rumors. The fact that news about important families like Tahirids are transferred through names who are close to the family is an example of this situation. The writer, while reflecting the entertainment life of the era via narration by famous singers of the day, also displays his knowledge on Arab poetry through 500 lines he quoted. In this study, which indicates to what extent historians benefited from the book Kitabu Baghdad as a source, list of the Ibn Tayfur's informants is given as appendix.

\section{Keywords}

Ibn Tayfur, Kitabu Baghdad, City History, Me'mun, Tahirids 
Tarihin garip tesadüflerle dolu olduğu gerçeği sık tekrarlanan bir klişe olsa da elimizdeki kitabın yazarı ve hayatını yazdığı Halife Me'mûn için oldukça uygun düşüyor. Halife Me'mûn kardeşiyle olan taht mücadelesini kazanmasından yıllar sonra Bağdat'a girdiği yıl doğan biri onun ve döneminin tarihini yazacaktı. Bu kişi İbn Tayfur'dur. Peki, İbn Tayfur kimdir?

\section{Yazarı: İbn Ebû Tâhir Tayfur}

Tam künyesi Ebü'l-Fazl Ahmed b. Ebî Tâhir Tayfûr Mervezî Horasânî'dir. 819'da Bağdat'ta Babüşşam'da veya bitişiğinde yer alan Harbiyye'deki Mervliler mahallesinde doğmuştur. Horasan'ın Merveruz şehrinden başkente gelmiş olan İbn Tayfur'un ataları Ebnâ-i Horasan denilen ve Abbasi davetini destekleyen ailelerden biridir. Hayatının ilk on üç yılını Me'mûn döneminde geçiren İbn Tayfur, eğitimini tamamladıktan sonra önce halka açık küttâbda bir süre muallimlik yapmış, daha sonra zengin ailelerin çocuklarına özel ders vermiştir. Bir süre sonra bunu da bırakıp muhtemelen 850'de Sûku'l-Varrâkîn'de bir yer edinip kitap istinsahıyla geçinmeye karar vermiştir. Aynı zamanda bir şair olan İbn Tayfur, zengin çevrelerdeki katı kuralları tanımayan özgür bir ruha ve tenkitçiliğiyle kendini dışa vuran sivri dilli bir kişiliğe sahip olduğu için bu çarşının nisbeten serbest ortamı onu çekmiş olmalıdır. Yeni dostlar ve arkadaşlar kazandığı bu çarşıdaki kitap ve kültürle iç içe geçen yılları, ona hem yeni bir edebi-kültürel ortam hem de birer kültür hazinesi olan eserlerinin malzemesini toplama imkânı sağlamıştır. Yetişkinken de Babüşşam'da oturan İbn Tayfur aldığı klasik eğitimin sonucu ve dükkânında kurduğu bağlantıları sayesinde önemli bir kültür tarihçisi, edebiyat eleştirmeni, antoloji yazarı ve yazar olmuştur. İbnü'l-Hatîb'e göre o; şair, ravi, belagat sahibi bir hatip, ilimle anılan zeki ve anlayış sahibi kimselerdendi. İbn Tayfur 15 Ağustos 893 Bağdat'ta öldü ve Bâbüşşam'a defnedildi. İbn Tayfur'un kaynaklarda sözü edilen çok sayıda eserinden Kitâbu Bă̆gâd'ın 6. cildi ile antoloji mahiyetindeki 14 ciltlik Kitâbü'l-Menŝûr ve'l-manẓ̂um isimli eserin 11, 13 ve 14 . ciltleri günümüze gelmiştir. (Hatib Bağdadî, 1417, s. 433; İbnü'n-Nedîm, 2019, s. 442; Hizmetli, 1999, s. 445) İbn Tayfur'un 50 kadar eserini tek tek sayan İbn Nedim'in ondan söz ederken Ca'fer b. Hamdan'dan naklen şunları aktarması ilginçtir: "Kitap yazma ve şiir söylemede onun kadar hata eden, hamakat gösteren ve bozuk iş yapan ondan daha meşhur bir kişi görmedim. Bana İshak b. Ali hakkında bir şiir okudu. Tam on küsur yerde yanlış yaptı. Ayrıca -bir beytin yarısı yahut üçte biri olsun- çalmakta ve intihalde çok mahirdi. Buhturî de bana böyle söyledi" (İbnü'n-Nedîm, 2019, s. 442). İbnü'n-Nedim'in 50 kadar eser yazmış bir yazar olarak tanıttığı, ne kadar titiz bir tarihçi olduğunu elimizdeki eserinden 
okuyucunun da rahatlıkla anlayabileceği bir adamdan bu şekilde söz etmesi haksızlık değil midir? Peki, İbnü'n-Nedim neden böyle yapmıştır. Çünkü İbn Tayfur, şairlerin intihalleriyle alakalı Kitâbü Serikâti'ş-şu'arâ adlı bir eser yazmış ve kendisini de intihal yapmakla suçlamıştır. O da gelecek nesillere İbn Tayfur'u hafızasına güvenilmez, intihalci ve çok hata yapan biri olarak tanıtarak bunun intikamını almıştır. ${ }^{1}$

\section{Baskıya Esas Nüshanın Tanıtımı:}

Kitâbu Bă̆dâd'1 1908'de ilk defa yayınlayarak ilim âlemine tanıtma ayrıcalığı Hans Keller'e aittir. Keller, British Museum'da 23318 numarada kayıtlı yazmanın bir kopyasını temin ederek işe başlamıştır. Keller'e göre yazma nüsha 264 sayfa olup her sayfada 14 satır bulunmaktadır. Bu nüshanın elimize olduğu gibi ulaşmasında hattatların sakarlığının rol oynadığını belirten Keller, bazı delillere dayanarak yazma nüshanın okutularak yazılmış bir nüsha olduğu sonucuna varmıştır(Keller, 2008 s. 5). İngilizceye çevrilen eser (New York 1920) daha sonra İzzet Attâr Hüseynî-Zâhid Kevserî tarafından yayımlanmıştır (Kahire 1368/1949; Beyrut-Bağdâd 1388/1968; Kahire 1972, 1415/1994). Eser son olarak 'İsâm Muhammed Hac Ali tarafindan tahkikli olarak (Beyrut 2009) yayımlanmıştır.

Halifelerin haberleri ve dönemleri diye de bilinen Kitâbu Bă̆dâd'in Halife Mühtedî dönemine kadar olan kısmını İbn Tayfur, devamını ise oğlu Ubeydullah yazmıştır. Bu kısım Mu'temid-alellah(870-892), Mu'tazıd-billah (892-902), Müktefî-billah (902-908), Muktedir-billah (908-932) dönemlerini kapsiyordu, fakat tamamlanamamıştır (İbnü'n-Nedîm, 2019, s. 442-444). Makrizî de bu bilgiyi teyit etmiş ve Ubeydullah $b$. Tayfur'un bu kısmı Halife Mu'tazıd-billah için yazdığını söylemiştir. Eserin tamamının 16 ciltten oluştuğunu söyleyebiliriz.(Makrizî, 1418, s. 2, 44; Keller, 2008, s.8). Ebû Hayyân Tevhîdî'nin, Besâir ve Zehâir' de aktardı̆̆g bazı anekdotlar, müellifin Emevî dönemine dair rivayetleri de topladığını dolayısıyla tarihinin o dönemi de kapsadığını düşündürmektedir. Suriyelilerin cengâveri (fârisu ehli'ş-Şam) Cerrah b. Abdullah(ö. 730) ve İbnü'l-Ertat hakkındaki anekdotlar (Ebû Hayyan Tevhidî, s. 4, 128, 4, 211) bunun delilidir. Erken Abbasi dönemine dair halife Ebû Ca'fer Mansur'un (754-775) günlük öğünlerinde sevdiği yemeklerden ve kâtiplerine kendisini önceki halifelerden hangisine benzettiklerini

\footnotetext{
${ }^{1}$ Kitâbu Bağdad = Sechster band des Kitab Bagdad, Ebü'l-Fazl b. Tayfur Ahmed b. Tayfur Bağdadi İbn Ebû Tâhir, 280/893; Deutsche übersetzung von Hans Keller; edited by Fuat Sezgin, Frankfurt am Main: Institut für Geschichte der Arabisch-Islamischen Wissenschaften an der Johann Wolfgang GoetheUniversität $=$ Institute for the History of Arabic-Islamic Science at the Johann Wolfgang Goethte University, 2008. XXVI, 159 s. (Islamic Geography; 299) Keller tarafından yazılan Almanca önsöz, s. 6. (bundan böyle Keller, Önsöz şeklinde verilecektir.)
} 
sorması ile mahallesine mescit yapılmasını isteyen adamla görüşmesinden söz eden üç anekdot (Ebû Hayyan Tevhidî, s. 1, 241; 2, 17, 18) ile Ali b. Ubeyde'nin Me'mûn'un kızı Ümmü Muhammed'in mektubunu cevaplaması (Ebû Hayyan Tevhidî, s. 4, 151. Eserde İbn Tayfur'dan yapılan diğer aktarımlar için ayrıca bkz. 4, 127, 148, 150, 174; 9, 15) gibi elimizdeki bölümde bulunmayan bilgiler de Ebû Hayyân Tevhîdî'nin İbn Tayfur'dan aktardığı rivayetler arasındadır.

\section{Eserin Yazıldı̆̆ $\mathbf{~ D o ̈ n e m ~}$}

Me'mûn döneminde yetişen müellif, Mu'tasım-Billah(833-842), Vâsık-Billah (842-847), Mütevekkil-Alellah(847-861), Müntasır-Billâh (861-862), MüstaînBillâh(862-866), Mu'tez-Billâh (866-869), Mühtedî-Billâh (869-870), Mu'temidAlellah (870-892) dönemlerini idrak ettikten sonra 893'te ölmüştür. Hârunürreşid'in ölümünden sonra iki kardeş arasındaki halifelik mücadelesi sonrasında kazanan Me'mûn'un Bağdat'a gelmeyip Merv'de kalmayı seçmesi sonucunda başkentte bir iktidar boşluğu meydana gelmiştir. Beş altı yıl süren bu kaos halifenin Bağdat’a gelişiyle sona ermiştir. Devletin karşı karşıya kaldığı meşruiyet krizini çözmek için Me'mûn, Alioğullarından Ali Rıza'yı veliaht atamış ve onların rengi olan yeşil renk kıyafeti giymiştir. Ancak bu kez de Abbasoğullarının hoşnutsuzluğuyla karşılaşmıştır. Onlar da tepki olarak kendilerine İbrahim b. Mehdî’yi halife seçmişlerdir. Bağdat'a gelirken yolda önce veziri İran kliğinin başı Fazl b. Sehl'in ardından veliaht Ali Rıza'nın şüpheli ölümü Me'mûn'un bu politikasının sonu olmuştur. Büyük bir ilim kültür merkezi olan Bağdat'a geldikten sonra akıllı halifenin Yunancadan yapılan çevirilere ilgi duyduğu belki de bu çeviri hareketini iktidar boşluğundan çıkış için bir çözüm olarak gördüğü söylenebilir. Bu yüzden de o döneme kadar bir merkezden yoksun olarak yürütülen tercüme faaliyetlerini kurduğu bir tür enstitü olan Beytülhikme'de yoğunlaştırması konuya verdiği önemi gösterir. Sarayda çeşitli ilmi ve kültürel konuların tartışıldığı ilim meclislerini kurması, Mutezile etkisiyle halkul-Kur'an mihnesini başlatması hep bu meşruiyet krizine karşı uygulanmış bilinçli politikalar olarak görülmelidir. Merkezde sağlanan görece sükûnet hali yanıltıcıydı. Doğuda Horasan'a atadığı valisi Tâhir b. Hüseyin bağımsızlığını ilan ederken Suriye ve Mısır'da isyan ve karışıklıklar kendini göstermiş, Azerbaycan'da Babek önderliğindeki dinî sosyal direniş (826-837) gittikçe yayılıyordu. İsyanları bastırmak için yoğun çaba sarf eden Me'mûn'un Bizans'a öldürücü darbe vurmaya hazırlanırken Tarsus'taki ani ölümü, bu ağır yükü halefi Mu'tasım'ın omuzlarına yükledi. Mu'tasım (833-847)Abbasi halifeliğinin yapısını değiştiren iki önemli olayı gerçekleştiren halifedir. Birincisi, paralı yabancı askerler getirterek dinî, siyasi ve ailevi çekişmelere gömülmüş Arap ve İranlılara karşı Türk, Slav ve Berberilerden kişisel muhafız birliği kurmasıdır. Bu birliklerin komutanları başlangıçta halifeye 
sadakatleri ile ona sağlam bir dayanak sağlarken zamanla siyasi rollerinin artmasıyla iktidarın tek hâkimleri olacaklardır. İkincisi Bağdat'tan ayrılarak yeni bir başkent kurmasıdır. Halkının hem mutezilî görüşteki halifeye düşmanlığı hem de muhafız birliğindeki Türklerden hoşlanmamaları Mu'tasım'ı 836 yılında Bağdat'ın 100 km kuzeyinde kurduğu Samerra'ya taşınmaya mecbur eder. Artık Abbasi halifeleri, kendilerine muhabbeti kaybetmiş olan Arapların ve İranlıların yerine muhafız birliklerinin ana unsuru olan Türklerin desteğinden yararlanmış ve onlara sıkı bir şekilde bağlanmıştır. Bu bağlılık sayesinde veliaht bırakmadan ölen Vâsiḳ-Billâh’ın kardeşi Ca'fer, Mütevekkil-Alellah lakabıyla halife ilân edilmiştir. Türk komutanların desteği ile halife olan Mütevekkil'in iktidarı Türklerden kurtulma çabaları ile geçmiş, ölümü de oğlunun da karıştığı bir suikast sonucu Türklerin elinden olmuştur. Gerçekten iktidar olmak isteyen son halife olan Mütevekkil döneminde sünnî tepkiler ortaya çıkmış, halife şiîlere, onların kutsallarına ve hatta şîiliği destekleyenlere savaş açmış, dönemi onlar için bir tür cadı avına dönüşmüştür. Zımmîler için de bir takım katı kurallar koymuşsa da öldürülmesi bunların uzun süreli olmasına izin vermemiştir. Mütevekkil'in ölümüyle birlikte Abbasi devletinin dağılma sürecine girdiği ikinci Samerra dönemi başlar. Bu dönem, Türk komutanların hanedan mensuplarından işlerine geleni halifeliğe getirdikleri, işlerine gelmeyince öldürüp yerine bir başkasını atadıkları bir dönem olur. Merkezi iktidarın gücünü kaybetmesi beraberinde çok sayıda isyanı ve kopmaları beraberinde getirmiştir. Müntasır (861-862)'dan itibaren tahta oturtulan beş halife döneminde dağılma ve çöküş hızlanmış, hazine boşaldığından isyancıların üzerine gönderilecek orduyu donatacak para bulunamaz hale gelmiştir. Samerra halifelerinin sonuncusu Mu'temid (870-892) döneminin önemli olayları zenci ve karmatî isyanlarıyla mücadele, Mısır ve Suriye'nin bağımsızlık kazanması, Türk nüfuzundan kurtulma girişimi olarak başkentin yeniden Bağdat'a taşınmasıdır. Mu'temid'in sorumsuzluğunu telafi eden en olumlu kararı kardeşi Muvaffak'1 devletin genelinin idaresiyle görevlendirmesi olmuştur. Kanlı çatışmalarla devam eden yeni iç savaş halifeleri yeniden Bağdat'a sığınmaya mecbur etmişse de Büveyhilerin 946'daki işgaline kadar halifeler sık sık Türk komutanların kılıcıyla burun buruna yaşamak ve iktidarlarını onlarla paylaşmak durumunda kalmışlardır. Başkentin Bağdat'a taşınmasıyla birlikte Samerra dönemi bitmiş ancak Türk nüfuzu dönemi bitmemiştir. Müktefi (902-908) döneminde hafifçe gevşeyen Türk nüfuzunun Muktedir (908-932) döneminden itibaren artarak güçlendiği ve Emirü'l-ümera unvanını alan Türk komutanların halifeler üzerindeki vesayetlerinin, Büveyhilerin 
946'da Bağdat'ı işgallerine kadar sürdüğü görülmektedir (Robert,1984, s. 123-125, 136-139; Brockelmann,1992, s. 100-102, 106-122; Emin, 2019, s. 226-232).

Hicri 3. Miladi 9. Asır büyük tarih kitaplarının yazıldığı bir dönemdir. Çoğu günümüze ulaşmayan bu eserlerin yazarları daha geniş bir tarih ufkuna ve görüşüne sahiptirler. Kabile ve mezhep etkilerinden kurtulmuş olan bu yazarlar İslam ümmetini Sünnî Abbasi halifesinin idaresinde tek bir devlet olarak görüyorlardı. 8. Asırdan beri bu alanda eser veren din âlimlerinin yanı sıra edebiyat, matematik ve tabii bilimler gibi alanlarda çalışan kâtipler vardı. Daha önceki milletlerin tarihinin yanında hadisler, şiirler ve edebiyat malzemesinden yararlandılar. Yazdıkları yıllara ve konulara göre İslam tarihlerinin baş kısmında yaratılış, peygamberler tarihi, Sâsânîler tarihinden söz eden bir giriş bulunmaktaydı. Bu giriş Ya'kubî tarihinde İslam'dan önceki bütün milletlerden söz eden bir dünya tarihine dönüşmüş, eski milletlerin kültür tarihinden de bahsedilmiştir. Müslüman tarihçiliğinin esaslarını kesin olarak ortaya koyan bu tarihçilerin ortaya çıkışı tarihçilikte ahbârîler döneminin sonunu gösterir. Bu tarihçilerin başında ilk Endülüs tarihlerinden birini yazan (Kitabü't-târîh) İbn Habib Kurtubî (ö. 853) ile İslam dünyasında ilk kronolojik tarihlerden birini telif eden Halife b. Hayyât (ö. 854-55) gelir. Bu ikisini Fütûhu Misr ve Ahbâruha müellifi İbn Abdülhakem (ö. 870), Uyûnu'l-ahbâr ve Meârif yazarı İbn Kuteybe (ö. 889), Fütûhü'lbüldân ve Ensâbü'l-eşrâf yazarı Belâzürî (ö. 892-893), Ahbaru't-tıval ve Kitâbu'n-nebat ile Ebû Hanife Dîneverî (ö. 895), Târîhü'l-Ya'kûbî ve Büldân müellifi Ya'kûbî (ö. 905), Târîh'i ile Ebû Zür'a (ö. 894) takip eder. Taberî (ö. 922) bu döneme kapanış mührünü Târîhu'r-rüsîl ve'l-mülûk'u ile vuran büyük tarihçidir. Bölgesel tarihle kültürü iç içe anlatmaları bakımından İbn Habib Kurtubî, İbn Abdülhakem, Belâzürî ve Ebû Hanife Dineverî, İbn Tayfur'un öncüleri sayılırlar. Son iki isim 9. Asırda İbn Tayfur'la aynı şehirde, Bağdat'ta yaşadıkları halde birbirlerinden yararlanmamış olmaları ilginçtir. Bu durum belki de Taberî'nin de benimsediği çağdaşlarından yararlanmama anlayışının bir göstergesidir. Sonuç olarak 9. Asrın sonunda tarih kavramının dinî temelinden ayrılmış olduğu ve ayrı bir bilim dalına katkı sunacak ölçüde genişlemiş olduğu Ya'kubî ve Mes'ûdî'nin eserlerinden anlaşılabilir. Sınırlı bir genel tarih anlayışı benimsenmiştir. Bu eserlerde İslam tarihine giriş olması bakımından yaratılış ile başlanır ve bir dünya tarihi özetiyle devam edilir. İslam'ın yükselişiyle birlikte diğer toplumların tarihi ya ikinci plana itilir ya da göz ardı edilir. Bu tutum tarihe duyulan ilginin artmasının açık bir yansımasıdır. Konumuz olan Kitâbu Bağdâd'ın yanında Cehşiyarî'nin (ö. 942-943) Târîhu'l-vüzera ve'l-küttâb'1 ve Sûlî'nin (ö. 946) edebi tarihi anıları derlediği Kitâbu'lEvrâk' 1 bu tavrın bariz örnekleri olarak karşımıza çıkar (Gibb, 1979, s. 786-787; 2017, s.91). 
Kitâbu Bă̆dâd'ın Tarihi Değeri| 113

\section{Müellifin Metodu ve Kaynakları}

\section{Metodu:}

Müellifin metodunun en ilginç yanı çağdaşı tarihçilerden farklı bir yol izlemiş olmasıdır. İbn Tayfur, Heysem b. Adî, Halife b. Hayyât, Taberî gibi tarihçilerin olayları kronolojik sırayla yıl esasına göre anlatımını tercih etmemiştir. $\mathrm{O}$, önce her halifeyi tek tek anlatmış, sonra dönemindeki siyasi olayları aktarmış, atadığ görevlilerle ilişkilerini anlattıktan sonra sözü sırasıyla ilim, edebiyat, şarkı ve eğlence meclislerine getirmiştir. $\mathrm{O}$ halifeye ayırdığı bölümün sonunda vefat eden önemli kişileri vefat tarihlerine göre sıralamıştır. Kullandığı bu yöntem ona çağdaşları arasında farklı ve eşsiz bir yer kazandırmıştır. Üslubunun diğer bir ayırıcı yönü sakin ve ağırbaşlı olmasıdır. Olayları tarafsız bir anlayışla yazan müellifin amacı herhangi bir tarafa kaymadan haber ve olayları ayıklamaktır. Temel gayesi herhangi bir mezhebe veya kişiye taassup göstermeden gerçeği ortaya çıkarmaktır. Onun tarzı duygu istismarı yapmadan ve duyuları coşturmadan yazdığı dönemin gerçeklerine ayna tutmak veya modern tabirle dönemin fotoğrafını çekmektir diyebiliriz. O yüzden üslubu normal okuyucuyu çeker ve eserini baştan sona soluksuz okumaya iter. Yazarın dilinin sadeliği ve kesintisiz büyüleyici anlatımı, ele aldığı konuları sıkmadan ve acele ettirmeden okuyucuya kavratır. Elimizdeki kısımda yer alan konular açısından bakıldığında müellifin daha çok bir kültür tarihi yazmaya çalıştığı görülmektedir. Ancak bunu siyasi tarihi göz ardı etmeden yapmış olması eserine ayrı bir farklılık ve renk katmaktadır.

Arapça kaynaklar incelendiğinde şehir ve bölge tarihlerinin başlangıcının, fütûh ve coğrafya literatürüyle bağlantılı olduğu ve bu yüzden İslam tarihinin ilk dönemlerine kadar götürülebileceği sonucunu çıkarmak mümkündür. Kâbe tarihi ve bununla ilgili rivayetlerin toplanması ve oradaki yazıtların çözülmesi merakıyla başlayan bu ilgi, Hz. Ömer döneminden itibaren yeni fethedilen Suriye, Misır, Irak, Horasan, İran vb. ülkelerin ikliminin insan üzerindeki etkilerinin sorgulanmasıyla artarak sürmüsştür. Böylece halifeler ve valiler için yapılan şehir ve bölge tasvirleri sonraları buraların coğrafyası ve tarihiyle ilgilenen müelliflerin ana malzemesini oluşturmuştur. Siyasi olayları anlatırken kullandığı dil ilmi veya felsefi bir dil olmayıp belâgatli tarih dilidir. Şairlerden söz ederken edebi ve şiirsel bir dil kullanır. Şarkılardan ve şarkıcılardan söz ederken teknik bir dil kullanır. Her durumda kullandığı bu metodu sayesinde, gerçeklerin aktarımından ödün vermeden okuyucunun zevk almasına özen gösterir. 


\section{Kaynakları:}

İbn Tayfur bu eseri hangi kaynaklardan yararlanarak yazdı? İbn Tayfur bağımsız bir tarihçidir. Bağdat ve Irak'ın tarihini ilk yazan odur. Kitâbu Bă̆dâd, özgün bir çalışmadır. Hiç kimseden etkilenmeden yazıldığını eserin planından ve anlatımından yani özgünlüğünden anlıyoruz. Müellif, birçok bilgiyi çeşitli kaynaklardan toplayarak bir araya getirmiştir. Bilgisini aktardığı olayın nerede geçtiğini bize söyler. Kaynaklarının çoğu şifahidir. Yararlandığı kâtip ve bürokratların sınırlı oluşu bize saraya pek nüfuz edemediğini düşündürmektedir. Fazl b. Rebi'nin amcası Yahya b. Hasan'dan belirli bilgileri almıştır. Yine Amr b. Mes'ade, Fazl b. Mervan, Ahmed b. Yusuf, Tâhir b. Hüseyin, Abdullah b. Tâhir, Muhammed b. Abdullah b. Tâhir, Hasan b. Sehl, Vâkidî gibi yüksek memurlar için çalışan kâtiplerden bilgi aldığı anlaşılmaktadır. Bunlar sayesinde kulislerin arkasına bakma şansını yakalamıştır. Bu ravi listesi Ali b. Ubeyde Reyhanî'den (ö. 219/834 [?]) söz edilmediği takdirde eksik kalacaktır. Merv'deyken Me'mûn'un nedimliğini yapmış olan bu zat Bağdat'a onunla birlikte gelmiş ve hemen hemen ölümüne kadar yanında bulunmuştur. İbn Tayfur, aynı zamanda hocası ve arkadaşı olan Ali b. Ubeyde Reyhanî'den pek çok haber aktarmıştır (Ebû Hayyân Tevhîdî, 2010, s. 4, 150; Yakut Hamevî, 1993, s. 1, 279; 1995, s. 4, 1814, 1816). Rosenthal'e göre İbn Tayfur, Bağdat'ı anlatırken kullandığı kültürel ve ekonomik istatistiki verileri çağdaşı olan iki tarihçiden almış olmalıdır. Bunlar Ahmed b. Ebu Tayyib Serahsî (ö. 899) ve Mu'tazid döneminde yaşayan Yezdecird b. Mühenbedaz Kisravî'dir. Fihrist'te Serahsî'nin böyle bir eserinden bahsedilmemiş, ancak Kisravî'nin Fezâilü Bă̆dad ve Suretuha isimli bir eserinden söz edilmektedir (İbnü'nNedim, 2019, s. 392; Rosenthal, 1968, s. 153). ${ }^{2}$

Eserde Kur'an-1 Kerim'den çok sayıda ayetin ve bazı hadislerin bulunduğunu hatırlatmakta yarar vardır. İbn Tayfur'un Kitâbu Bă̆gâd'daki kaynaklarından söz etmeden önce onun Irak'ın ve Bağdâd'ın tarihini yazan ilk kişi olduğunu ve o sırada konuyla ilgili elinde yazılı eser bulunmadığını akılda tutmamız gerekir. Bu yüzden de kitabında eski tarihçilerden kimsenin adını vermemiştir. Peki, müellif bilgilerini nerden almıştır? İbn Tayfur'un verdiği bilgiler kişisel gözlemlerine, bizzat işittiklerine dayanmaktadır. Müellif, eserindeki bilgileri toplarken gerçekleşen olaya yer ve zaman olarak kendisinden daha yakın olan çağdaşı râvilerden yararlanmıştır. Doğal olarak her zaman müellifin saraya (dârülhilâfe) bizzat ulaşma imkânı yoktu. Haliyle halifelerin haberlerine çok yakından tanık olma şansı da bulamamış olmalıdır. Bu yüzden de onlar hakkındaki haberleri öğreneceği râviler halifenin maiyetinde bulunan kişiler, nedimleri, gece sohbeti

\footnotetext{
${ }^{2}$ Hilal b. Muhassin, ondan Fezailü Bağdad Irak yazarı Yezdecird b. Muhebendar Farisî olarak söz eder. Rüsumu dâru'l-hilafe, thk. M. Avvad, Beyrut 1986, s.18.
} 
arkadaşları veya onların haberlerini izleyen ileri gelenlerden (ayan) oluşuyordu. Müellif pek çok kişinin rivayetini aktarmıştır. Bir konuyla ilgili haber aktaracağ zaman ya sika bir muhaddise ya da bir görgü tanığına dayanmak durumundaydı. Birden çok rivayet geldiğinde ise aralarından tanıklarca doğru kabul edileni seçerek hem vereceği haberi sağlam bir temele dayandırmış hem de eserine yöneltilebilecek eleştiri ve kuşkuları da uzaklaştırmış olur. Bu duyarlığın bir gereği olarak ismi verilen râvi veya râvilerin aktardıkları haber veya bilginin dârülhilâfedeki siyasi, sosyal veya mesleki konumlarıyla doğrudan ilgili olduğunu görürüz. Bu yüzden çok sayıda râvi bir haberde ittifak ettikleri takdirde onu "tarihçiler dediler ki:" veya "hepsi/hep birlikte şöyle dediler" ifadesiyle aktarır. Ancak bu râvilerden biri, bir haberi tek başına bildirmişse "falanın bana bildirdiğine göre, falan bana bildirdi ve dedi ki" sözleriyle aktarır. Bu durumda haberin aktaran kişiye göre değer kazanacağı açıtır. Bu yöntem eserden yararlanacak kişinin işini kolaylaştıracaktır. Bu da müellifin kavrayış ve yazımda usta, çok yetenekli bir tarihçi olduğunun kanıtıdır. İbn Tayfur'un sözünü ettiğimiz bu niteliklerini eserine nasıl yansıttığını Kitâbu Bă̆dâd'daki râvilerin önemlilerine yakından bakarak görebiliriz.

Me'mûn'un Horasan dönüşü haberini verirken söze şöyle başlar: "Râvilerden bir topluluk zikretti ki: İshak b. Süleyman Hâşimî, Ebû Hassan Ziyadî, İbn Şebâne Mervezî, ellerindeki tarih kitaplarından naklettiklerine göre hepsi ittifakla dediler ki:" $\mathrm{Bu}$ onun rivayetleri rastgele yazmadığının, tarihçilikteki ustalığının göstergesidir. Yazım teknik ve usullerini iyi bilen yazar, râvilerinin ilmi konumlarının sınırlarını görebilecek kadar bilgili ve ustadır. Mesela Ebû Hassan Ziyadî, güvenilir bir muhaddis ve tarihçi olarak görülür. Mütevekkil döneminde kadılık yapmıştır. Kitâbu't-târîh ale's-sinîn adlı eseri, İbn Tayfur'un önemli kaynaklarından olup Hatîb Bağdâdî bu eseri Târîhu Bă̆gâd'ında övdüğü gibi, Mes'udî ve İbn Makula da zikretmiştir (Sezgin, 2015, s. 1, 360-361).

Me'mûn'un haberlerini araştırırken müellifin, fesahat ve belagatla nitelenen ve övülen İbrâhîm b. Abbâs Sûlî (ö. 244/858)'nin rivayetini aktardığını görüyoruz. Yine aynı konuda birçok yerde İbrahim'in amcazadesi ve Me'mûn'un vezirlerinden biri olan Kâtip Amr b. Mes'ade'nin (ö. 217/832) rivayetlerine yer verdiğini görüyoruz. Öte yandan faziletli edip ve râvilerden, Tabakâtü'ş-şu'arâ kaleme almış bir şair olan İsmail b. Ebû Muhammed Yezîdî'nin (ö. 883-884) rivayetlerini de dikkate alır. Harunürreşid ve Emin'in veziri Fazl b. Rebi'nin dayısı Ebû Zekeriyya Yahya b. Hasan b. Abdülhâlik'ın rivayetlerini ihmal etmemiştir. Hatta öneminden dolayı bu kişi, İbn Tayfur'un birçok haberde dayandığı râvidir. 
Me'mûn'un ve Tâhir b. Hüseyin ailesinin haberlerini ezbere bilen Muhammed $b$. Abdullah b. Tâhir'in kâtibi Muhammed b. İsa'nın rivayetlerine de önem vermiştir.

Abdullah b. Tâhir'in Nasr b. Şebes'le savaşmaya gidişinden söz ederken yeniden Ebû Hassan Ziyadî ve Muhammed b. Musa Harizmî'nin rivayetine döner. Mu'tasım'ın veziri Fazl b. Mervan'ın rivayetini de gözden kaçırmaz.

Me'mûn'un Bağdat'taki siyasetini ele alırken dayandığı râviler arasında Ca'fer b. Muhammed Enmâtî, Abdullah b. Tâhir, Mu'tezilenin ileri gelenlerinden Sümâme b. Eşres, Vâkidî'nin kâtibi Muhammed b. Sa'd, Kadı Yahya b. Eksem bulunmaktadır. Me'mûn'un affından söz ederken Basralı tarihçi, şair ve dil ustası Ebû Abdurrahman Muhammed b. Ubeydullah b. Amr Utbî'nin (ö. 842) rivayetini aktarır.

Tâhir b. Hüseyin'in haberlerini yazarken Tâhir ailesi fertlerinin bilgilerinden yararlanır. Bu konuda Ebü'l-Abbas Muhammed b. Ali b. Tâhir, Ebû Muhammed Mutahhar b. Tâhir, Horasanlı Kâtip Muhammed b. İsa, Tâhir'in yemek ve sohbet arkadaşı olup yanında konumu yüksek olan Ebü'l-Heysem Halid b. Hammâd gibi önemli ve yakın kişilerin rivayetlerine yer verir. Bu konuda öne çıkan rivayetler arasinda Muhammed b. Abbas Sa'leb, Yahya b. Eksem, Yahya b. Hasan b. Abdülhâlik'ın aktardığı haberler bulunmaktadır. Abdullah b. Tâhir'in haberlerini aktarırken ise Muhammed b. Heysem b. Adî, Me'mûn'un veziri, fasih ve iş bilen bir kâtip olan Ahmed b. Ebû Halid Ahval'in (ö. 825) rivayetlerine yer verir.

Abdullah b. Tâhir'in Ubeydullah b. Serî ile savaşmak üzere Mısır'a gidişinden konunun öneminden dolayı tarihçilerden bir grubun tanıklığına başvurmuştur. Haberi şöyle aktarıyor: "Ebû Hassân Ziyâdî, Haşimî, Harizmî ve tarihçilerin hepsi dedi ki". Daha sonra konuyla ilgili olarak Tabip Ahmed b. Yunus Harranî, Me'mûn'un sır kâtibi, Horasan Berid'i ve Basra zekât sorumlusu Ahmed b. Yusuf'un oğlu Abdullah b. Ahmed b. Yusuf'un rivayetlerine yer verir. Ardından sika abidlerden Ebû Muhammed Abbas b. Abdullah b. Ebû İsa Turkufî ile Abdullah b. Tâhir'in nedimi Ebü's-Semrâ'nın rivayetlerini aktarır.

İbrahim b. Aişe'nin öldürülmesi konusunu anlatırken İbn Şübâne, Mu'tasım'ın kâtibi Fazl b. Mervan, Yahya b. Hasan'ın rivayetlerinden yararlanır. Me'mûn'un yokluğunda hilafeti gasp eden amcası İbrahim b. Mehdî'ye karşı konumundan söz ederken Me'mûn'un veziri Ebû Abbâd Sabit b. Yahya Râzî'nin çocuğunun öğretmeni Ebû Yakub'un rivayetini öne çıarır. Konuyu Sümame b. Eşres'in kardeşi Abdulvehhab b. Eşres'in rivayetiyle tamamlar.

Me'mûn'un veziri Ahmed b. Yusuf b. Kasım'in haberlerini verirken aile bireylerinin rivayetlerinden yararlanır. Müellif haberin kaynağı olması bakımından kendi rivayetlerinin yanı sıra Ebü't-Tîb b. Abdullah b. Ahmed b. 
Yusuf, Kâtib Ahmed b. Kasım, Ahmed b. Yusuf'un mevlası uşak (Hâdim) Nasr'ın aktardığ 1 haberlerle konuyu anlatır.

Kerec emiri ve kavminin efendisi Ebû Dülef Kasım b. İsa b. İdris İclî́nin haberlerini anlatırken Kasım b. Yusuf'un mevlası Zarîf, Kâtib Ahmed b. Kâsım İclî, dönemin şairi Hamâse sahibi Ebû Temmâm Tâî ve uşağı Salih'in rivayetlerinden yararlanir.

Me'mûn'un Bizanslilarla savaşmak için Şam'a gidişi konusunda İbn Tayfur'un kendi rivayetleri öne çıkmakta ve hiçbir râviye dayanma gereği duymamaktadır. Aynı durum Ali b. Hişam Mervezî’nin öldürülmesi konusunda da geçerlidir. Demek oluyor ki bu iki konuda da müellif olayı çok yakından izleme şansı bulmuştur. Belki de Me'mûn'un bu yolculuğuna İbn Tayfur da katılmıştır veya katılanlardan biri çok yakın arkadaşıdır. Böylece olayları doğrudan aktarma fırsatı bulmuştur. $\mathrm{Bu}$ arada belirtmeliyiz ki müellifin bizzat kendisine dayandığ rivayetlerin sayısı otuz birdir. Me'mûn'un Dımaşk'a varması ve orada şarkı dinlemesi konusunda Muhammed Hâşimî, Me'mûn'un mugannisi Muhârik, Ebû Haşîşe Tanburî lakaplı Muhammed b. Ali b. Ümeyye b. Amr'nin rivayetleri ön plandadir.

\section{Edebî Bilgiler}

Şairler ve onlarla ilgili olaylar konusunda şairlerin kendi rivayetleri yoluyla bilgi sahibi oluyoruz. Şiir sanatının uzmanları şairlerin hem akran ve çağdaşları ile hem de halifeyle ilişkileri kendi aralarında da en önemli merak konusu olduğundan şiir camiasıyla ilgili gelişmeleri yakından izlemekteydiler. Bu yüzden de İbn Tayfur, bu konuda Umâre b. Akîl, Ebü'l-Atâhiyye, Ebû Nizar Darîr gibi şairler ile Ebû'ş-Şemmâh ve Di'bil Huzâî'nin kardeşinin oğlu Süleyman b. Rezîn Huzâî'nin rivayetlerini kullanmıştır. Bu konuyu tamamlamak için de Muhammed b. Heysem, Me'mûn'un cariyesi Arîb'in mevlası Ebû Musa Merakibî ve Edip Ahmed b. Muhammed Yezîdî'nin rivayetlerinden yararlanmıştır.

Müellif, şarkılar ve şarkıcıların haberleri hakkında kâtipler, şairler ve şarkıcıların bizzat kendilerinden sağladığı bilgilere dayanmıştır. Burada rivayetlerinden yararlanılanlar arasında Kâtip Ebü'l-Kasım Abbas b. Ahmed b. Ebân, şair Hüseyin b. Dahhâk, Muhammed b. Ali b. Tâhir, sikâ muhaddis Muhammed b. Abdullah b. Tahmân bulunmaktadır. İshak Mevsilî, Allüveyh A'ser, Amr b. Bâne gibi mugannilerin rivayetlerini aktarmıştır.

İbn Tayfur, Me'mûn'un vefatıyla ilgili haber Kârî Saîd Allâf'in dilinden aktarmaktadır. Me'mûn döneminde vefat edenlerle ilgili haberlerin çoğunu Ebû 
Hassan Ziyâdî'den, birini ise Harizmî'den aktarmıştır. Bu başlıkla birlikte kitabın elimizdeki kısmı bitmiş olmaktadır.

Kitâbu Bağdâd'ın edebiyat tarihi bakımından da önemli olduğu kanısındayız. Arap şiiri ve nesri açısından önemli metinler bulunmaktadır. Eserin, Me'mûn'un mektupları başta olmak üzere divandan yazılan çeşitli yazışma örneklerini barındırması bu metinlerin gelecek nesillere ulaştırılması yönüyle önemlidir. Tâhiroğulları hanedanının kurucusu ve Me'mûn'un Horasan Valisi Tâhir b. Hüseyin tarafından oğlu Abdullah b. Tâhir'e vali atanması dolayısıyla yazılan vasiyetname, muhtevası bakımından siyasetname örnekleri arasında eşsiz bir yere sahiptir. Müellif, halk tarafından çok okunup çoğaltılarak elden ele dolaştırılan vasiyet mektubunun ününün Me'mûn'a kadar ulaştığını dile getirmektedir. Vasiyet mektubunu getirtip okutan Me'mûn şu sözlerle takdirini dile getirmiştir: "Ebü't-Tayyib din ve dünya işleri, tedbir, görüş, siyaset, saltanatın (mülk) ve uyruğun 1slahı, bi'atın korunması, halifelere itaat, hilafetin güçlendirilmesi konularında hiçbir şeyi ihmal etmemiş, mükemmel açıklamış, vasiyet etmiş ve öncülük etmiştir." (İbn Tayfur, 1949/1368, s. 27). Me'mûn bu vasiyetnamenin çoğaltılıp vilayetlerde görev yapan bütün valilere gönderilmesini emretmiştir. Bu da mektubun dönemin siyaset ahlakı açısından önemli olan tüm hususları kapsadığını ve bu yüzden Halife Me'mûn tarafından Abbasi devleti topraklarında yaygınlaştırılmaya çalışıldığını göstermektedir.

Eserde Me'mûn'un Bizans İmparatoru Teofil'in mektubuna cevabı başta olmak üzere taziye mektupları, Nasr b. Şebes'e verilen aman mektubu, zafer kutlama mektubu ve Halife Me'mûn tarafından Bağdat'taki vekiline yazılan halku'1-Kuran mihnesiyle ilgili talimatlar içeren mektuplar da eserde yer alan yazışma örnekleri arasında bulunmaktadir.

Şiir konusuna gelince birçoğunun divanı günümüze ulaşmayan çok sayıda Arap şairinin (90 şair) 500 kadar beytini içermesi, müellifin anlattığ hemen her konuyu şiirle destekleyecek kadar döneminin Arap şiirini iyi bildiğini göstermektedir. Şair ve râvilerden aktardığı birçok şiirin basılı divanlarda yer almamış olması, İbn Tayfur'un şiir hafızasının gücünü ve kaynaklarının genişliğini göstermesi bakımından önemlidir. Kitâbu Bă̆dâd, birçok şairin divan ve antolojilerde yer almayan şiirlerini kaybolmaktan koruması ve bizlere ulaştırması bakımından ayrı bir öneme sahiptir.

\section{Tarihçilerin Kaynağı Olarak Kitâbu Băğdâd}

Kitâbu Bă̆gâd'ın erken dönemde yazılmış bir Bağdat ve Irak tarihi olması bakımından kendisinden sonra gelen Taberî, Mes'udî, Ebü'l-Ferec Isfahanî ve Hatîb Bağdâdî gibi birçok tarihçinin önemli kaynaklarından biri olmuştur. Taberî, Kitâbu Bă̆gâd'ı kaynak olarak kullandığını açıkça söyler. Taberî'nin Târîhu'r-rüsûl 
ve'l-mülûk'u ile Kitâbu Bă̆dâd'ın metinleri karşılaştırıldığında Taberî'nin müellifimizden birçok haber aldığı görülür. Taberî tarihinin İbn Tayfur'un Kitâbu Bă̆dâd'1 ile ilişkisini aşağıda detaylı inceleyeceğiz.

Kitâbu Bă̆dâd Muhammed b. Yezîd Ezdî'nin tarihinde Me'mûn dönemi haberlerini verirken yararlandığı önemli kaynaklardan biridir. Nitekim yayıncı da eserin girişinde İbn Ebû Tâhir Tayfur'un Ezdî'nin yararlandığı önemli kaynaklardan biri olduğunu belirtmiştir. Bazı haberlerde İbn Tayfur'un eserinin elimizdeki 6. cildine atıf yapan Ezdî'nin, bazı haberleri ise onun adını vermeden ancak Kitâbu Băğdâd'dakiyle benzer şekilde aktardığ görülmektedir. Bu durumda Ezdî, İbn Tayfur'un adını sehven veya bilerek zikretmemiş veyahut aynı bilgileri başka kaynaklardan almıştır. Eğer bu sonuncu durum geçerliyse iki müellifin bazı haberlerde kaynaklarının ortak olduğunu düşünebiliriz. Belki de Taberî̀nin etkisinde bir müellif olan Ezdî'nin hocasının yaptığı gibi kaynağını bilinçli olarak gizlediğini düşünebiliriz. Durum ne olursa olsun İbn Tayfur, Ezdî'nin Târîhu'lmevsıl' da yararlandığı önemli kaynaklardan biridir (Ezdî, 1967, s. 11, 392, 401, 402, 405, 408, 409, 412, 413; Özaydın, 1995, s. 12, 48-49).

Ebü'l-Ferec Isfahanî de Egânî adlı eserinde İbn Tayfur'dan aktardığı çok sayıda haber ve anekdota yer vermiştir. Kitâbu Bă̆gâd'dan çok fazla yararlanan Isfahanî, bazı haberleri İbn Tayfur'un eserinin 6. cildinden aynen alırken, "Şu şu kişi bana şöyle dedi Ahmed b. Ebû Tâhir ona şöyle anlatmış" şeklinde aktarımda bulunmuştur. Bazı bilgileri ise "Ahmed b. Ebû Tâhir şöyle dedi" diyerek anlatmaya başlar. Bu ifade aktarılan bilginin elimizdeki 6. cildin dışındaki ciltlerden alındığını gösterir. Bazı bilgiler ise her iki kitapta da içerik olarak benzerdir. Bu bilgiler muhtemelen Isfahanî'nin doğrudan İbn Tayfur'dan almadığını, her iki müellifin kaynağının ortak olduğunu gösterir. Bu iki eserin bu kadar benzer olması nasıl mümkün oluyor? Isfahanî'nin Kitâbu Bağgâd haricinde

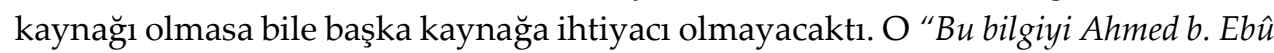
Tâhir'in kitabından yazdım" demiştir. Hatta yazarın hatalarını da aynen kopya etmiştir. Bu durum ise Isfahanî'nin Kitâbu Bă̆dâd'ı bizzat görmediğini, bu bilgileri başka kaynaklardan aldığını gösterir(Keller, 2008, s. 10-11). Isfahanî, kimi aktarımlarında İbn Tayfur'u açıkça belirtirken diğer bir bölümünden sehven veya bilerek zikretmemiştir. Onun Egânı̂'de aktarıp İbn Tayfur'a ait olduğunu belirttiği diğer Abbasi halifeleriyle alakalı birçok haber elimizdeki eserde bulunmamaktadır. Bu da Isfahanî'nin Kitâbu Bağdâd'ın kayıp bölümlerinden faydalanmış olduğu gerçeğini ortaya koymaktadır. Mes'udî, Murûcü'z-zeheb adlı eserinde İbn Tayfur'dan aktardığı haberlerde müellifimizin ismini vermiştir. O, Babek 
hakkındaki rivayetinde "bu bilgileri Ahbaru Bă̆dâd'da buldum" demiştir(Mesudî, 2017, s. 398-399). Yakut Hamevî, Kitâbu Bağdâd'dan yararlanmıştır. Onun, Hulvan'da Halife Harunürreşid'in hastalanmasından söz ederken aktardığı haberin kaynağı İbn Tayfur'dur. Oğlu Ubeydullah'tan ise Abdülaziz b. Süleyman hakkında bir anekdot aktarır(Yakut Hamevi, 1993, s. 3, 49; 1995 s. 2, 292). Hatîb Bağdâdî de Târîhu Bağdâd ev medinetü's-selâm adlı eserinde İbn Tayfur'dan nakiller yapmıştır. Bağdat'ın topografyasını anlattığı 1. ciltte ondan yedi rivayet aktarmıştır. O, bazı rivayetleri ise oğlu Ubeydullah aracılığıyla babası İbn Ebû Tâhir'den şeklinde aktarmıştır(Hatib Bağdadî, 1417, s. 1, 69, 102, 106, 130, 132, 314, 316; 3, 389; 4, 114; 7, 28, 70; 8, 243; 12, 165, 487; 13, 155; 19, 141). İbn Abdurabbih, Ikdu'l-Ferid' de İbn Tayfur'dan dört aktarımda bulunur(İbn Abdü Rabbih, 1404, s. 2, 262; 4, 275; 7, 315, 316). İbnü'l-Cevzî, Muntazam'da İbn Tayfur'dan sekiz rivayet aktarmıştır(İbnü'l-Cevzî, 1992, s. 8, 58, 81; 10, 189, 191, 229; 11, 108, 157; 13, 46). İbn Kesir, Taberî üzerinden Kitâbu Bă̆gâd'ı kaynak olarak kullanmıştır. Başka birçok tarihçinin eserinde İbn Tayfur kaynaklı haberler bulunmaktadır. Ancak bunlar doğrudan onun eserinden mi alınmıştır yoksa ondan aktarımda bulunan Taberî, Isfahanî, Hatîb Bağdâdî gibi tarihçilerin eserlerinden mi alınmıştır sorusuna net bir cevap vermemiz mümkün değildir. İleride yapılacak karşılaştırmalı çalışmaların bu ve benzeri soruları cevaplandırması araştırmacıların önünde yeni ufuklar açacaktır. Müellifin çağdaşları İbn Kuteybe, Belazürî, Yakubî ve Müberred'in kendisinden aktarımda bulunmamaya özen gösterdikleri anlaşılıyor.

Humeydî'nin Ahmed b. Muhammed Râzî Kinânî'nin (ö. 344/955 [?]) Aḩbâru mülûki'l-Endelüs adlı eserini tanıtırken onun Kurtuba'nın bölümlerini ve sakinlerinin yaşadığı konakları anlatırken Ahmed b. Ebû Tâhir'in Ahbaru Bă̆dâd'daki Bağdat tasvirini model aldığından söz etmesi İbn Tayfur'un etkisinin Endülüs'e kadar uzandığını göstermesi bakımından önemlidir (Humeydî, 1966, s. 104).

\section{Kitâbu Bağdâd-Taberî Tarihi İlişkisi Üzerine ${ }^{3}$}

Kitâbu Bă̆gâd'ın değerlendirmesine ayırdığımız bir yazıda neden başka bir alt başlık değil de elimizdeki eserin Taberî tarihi ile ilişkisi üzerinde durduğumuz sorusu akla gelebilir. Aslında eserin Biritish Museum'daki yazma nüshasının kopyasını temin edip ilk kez yayınlayan Hans Keller'in önsözü ve devamında, 1326. sayfalar arasında, bulunan bu başlıkta yazdığı yazısını görene kadar böyle bir niyetimiz yoktu. Ancak Keller'in iki eserin ilişkisine bu kadar geniş yer ayırması

\footnotetext{
${ }^{3}$ Bu başlıktaki hususlar Hans Keller'in Almanca neşirde Kitâbu Bağdâd'ın girişinde yazdığı yazıdan özetlenmiştir.
} 
bize özetle de olsa okuyucuyu bundan haberdar etmenin yerinde olacağına inandird $1^{4}$.

Keller'e göre, İbn Tayfur bilgileri derli toplu ve bir arada verirken, Taberî dağınık bir halde sunar. Keller'e göre, Taberî'nin doğrudan İbn Tayfur'dan yararlanmadığını ispat için ileri sürülen noktalar: Taberî, Kitâbu Bă̆dâd'ın bazı bölümlerini hiç dikkate almamıştır. Eseri de onda bulunmayan bilgiler içerir. Taberî, farklı birçok râviyi yüzlerce kez anmasına rağmen İbn Tayfur'u bir kez anmıştır(Keller, 2008, s. 13). Ayrıca Keller'in Taberî'nin İbn Tayfur'dan doğrudan yararlandığına dair delilleri: Taberî, Kitâbu Bă̆gâd'daki yanlış bilgileri ve yazım yanlışlarını aynen almıştır. İki eseri karşılaştırdığımızda Kitâbu Bă̆dâd'ın Taberî'nin ana kaynağı olduğunu görürüz. Taberî'de 6. cildin kapsamı 2200 satıra denk geliyor. Bunların 2000 satırı Kitâbu Bă̆dâd'dan alınmıştır. Mesela bir yerde İbn Tayfur kâle dedikten sonra yedi âlimden söz eder. Taberî kâle'yi getirir ancak yedi âlimi, yani senedi atladığı için bu bir şey ifade etmez. Aralarındaki nicel fark Taberî'deki 2200 satırın 2000 satırı İbn Tayfur'dan 200 satırı diğer kroniklerden alınmıştır. Bunun sebebi Taberî'nin asıl kaynağını gizlemek istemesidir. Nitel farklara geldiğimizde iki eser arasındaki ana farkın İbn Tayfur'un vakanüvislerin etkisinden kurtulması ve bir kültür tarihi oluşturmayı denemesidir. Taberî ise, bir yıllık oluşturmayı istediğinden bu malzemeyi bilinçli olarak dışarda tutmuştur. Bu nokta iki eser arasındaki en temel farktır. İbn Tayfur meseleler hakkında kafa yormuş, Taberî sadece toplamakla yetinmiştir. Eserini yazarken İbn Tayfur kapsamlı ve çok yönlü değerlendirmelerde bulunmuş ve bizi etkilemeye çalışmamıştır. Taberî ise sistem adamıdır, iktidara göre konuşmuştur. Taberî'nin İbn Tayfur'un eserinde yer alan bazı bilgileri eserini kısaltmak için almadığı savunulmuştur, ancak bu doğru değildir. Taberî bunu eserini kısaltmak için yapmamıştır. İki eser karşılaştırıldığında görülecektir ki Taberî, Abbasi tarihi ile ilgili bilgilerde İbn Tayfur'un Kitâbu Bağdâd'ından yararlanmış, hatta ihtiyacı olan bilgileri kelime kelime almış, ancak kaynağını belirtmeye cesaret etmemiştir. Çünkü eserine İbn Tayfur'dan aldıkları dışında çok az bilgi aldığı ve bunlar kuru bilgiler olduğu için asıl kaynağı vermeyi göze alamamıştır. Taberî eserinde sadece önemli olayları yansıtmak istediğinden İbn Tayfur'un ilgili bölümünün üçte ikisini almamıştır. Bu tavrı eseri kısaltmak için sonradan alınmış bir karar değil, baştan planladı̆̆ı bir şeydir. Taberî bu ihmalleriyle üç şeyi amaçlamıştır: Anlatımda kısalık, halifeliği zor durumda bırakacak bilgilerin göz ardı edilmesi ve

\footnotetext{
${ }^{4}$ Keller'in Almanca önsözünü okuyup özetleme nezaketini gösteren doktora öğrencisi Arş. Gör. Mustafa Yanç'a teşekkürü zevkli bir borç bilirim.
} 
yararlandığı kaynağın inkârı. Bu yaptığının biz okuyuculara yansıyan sonucu şudur: Bizi dönemin olaylarını anlama bakımından önemli olacak birçok ayrıntıdan mahrum bırakmıştır. Taberî'nin yaptığı elemelerde genelde sübjektif bir yaklaşımla karşı karşıyayız. Böylelikle gözlerimiz köreltiliyor veya kamaştırılıyor ve olayın aslını göremiyoruz(Keller, 2008, s. 13, 14, 16, 22, 23, 24, 26). Kıftî, 309 yılına kadar olan Abbasi tarihi olaylarını Taberî tarihinden okumak gerektiğini, ondan azami fayda sağlamak için İbn Tayfur ve oğlu Ubeydullah'ın yazdığı Kitâbu Bă̆dâd ile karşılaştırmanın yerinde olacağını belirtir. Çünkü ona göre Kitâbu Băgdâd, Taberî tarihinde bulunmayan bilgiler içermektedir(İbnü'l-Kıftî, 2005, s. 89). Bu ifade Keller'in, Taberî'nin olayları anlatırken ayrıntıları atlayarak İbn Tayfur'dan yararlandığı tezini açıkça desteklemektedir.

\section{Kitâbu Bağdâd'ın Konusu}

Halife Me'mûn'un Horasan'dan Bağdat'a gelişiyle başlayan elimizdeki 6. cilt onun Pozantı'da vefatıyla son bulmaktadır. Bu ciltteki konular altı bölümde anlatılmıştır. Birinci bölüm Abdullah Me'mûn'un halifeliği başlığını taşıyor. Bu bölüm iki kısma ayrılmıştır. Me'mûn'un Bağdat'taki siyaseti başlıklı ilk kısmın konuları şunlardır: Me'mûn'un Horasan'dan Bağdat'a gelişi, Rusafede konaklaması, Dicle kıyısındaki sarayına taşınması, Tâhir b. Hüseyin'in huzuruna girmesi, Bağdat halkının önce Me'mûn'u hoşnut etmek için Abbasilerin siyah rengi kıyafetlerini çıkarıp Alioğullarının rengi olan yeşili giymeleri, sonra Me'mûn'un siyah renge dönmesi üzerine tekrar siyah giyinmeleri, askerlerin maaşlarının ödenmesini istemeleri, Ahmed b. Ebû Halid Ahval'in Me'mûn'la görüşmesi, Halifenin Talibîleri karşılaması, Me'mûn'un Fazl'1 küçümsemesi, İmam Ali (a. s.)'1 Abbas b. Abdülmuttalib'e üstün tutması, halifenin Emin'in veziri Fazl b. Rebi'e karşı tutumu, Emin'in annesi Zübeyde'nin Me'mûn'dan şefkat istemesi, Me'mûn'un Tâhir b. Hüseyin'e karşı tutumu ve onu Horasan valiliğine ataması.

Bölümün ikinci kısmına müellif “Abdullah b. Tâhir'in Nasr b. Şebes'le savaşmak için Mudar'a gidişi” başlığını seçmiştir. Nasr b. Şebes'le savaşmak üzere Mudar valiliğine atanan Abdullah b. Tâhir'in Fazl b. Rebi'ye danıştıktan sonra yola çıkması, Tâhir b. Hüseyin'in vali atanan oğlu Abdullah'a vasiyeti, beğenilen vasiyetin halifeliğin bütün âmillerine dağıtılması, Tâhir'in Horasan valiliğine atanmasının sebebi ve oraya gidişi, Abdullah'ın Nasr b. Şebes'i yenmesi bu kısmın başlıca konularıdır.

Me'mûn'un Bağdat'taki Hikâyesi başlıklı ikinci bölüm iki kısımdan oluşmaktadır: Me'mûn'un ve arkadaşları, komutanları, kâtipleri ve haciplerinin ilginç hikâyeleri ile Me'mûn'un hilmi, iyi işleri ve yüce ahlak1/asalet göstergesi nitelikleri. İlk kısımda İbn Tayfur şu konularda bilgi sunuyor: Me'mûn'un yemeklerin yarar ve zararlarını açıklaması, şair Hüseyin b. Dahhâk'ı meclisinden 
çıkarması, mürtedin biriyle münazarası, kendisini ayıplayan zahitlerden biriyle münakaşası, İbrahim b. Sindî'yi İstihbarat sorumlusu ataması, İmam Ali (a.s.)'ın üstünlüğünü delillendirmesi, Nebi(sav)'in bıraktıklarını kutsal sayması, Me'mûn'un Bişr Merisî-Abdülaziz Kinanî münazarası, cesaret ve cesurlardan söz edilmesi, Abdullah b. Ziba'ra'nın Allah elçisinden özür dileyen kasidesini dinlemesi, Me'mûn'un oğlu Abbas'a öğüdü, minberlerde Muaviye'ye lanet okutmaya azmetmesi ve bundan vazgeçmesi, gezgin doktorla ilgili hikâye.

İkinci bölümün ikinci kısmında müellif Me'mûn'un hilmi ve iyi fiilleri üzerinde yoğunlaşarak Me'mûn'un tasını çalan hizmetçisiyle ilgili kıssa başta olmak üzere, Bişr Merisi ile olan hikâyesi, Hemedan valisi hakkında haber vermesi, adamlarının durumlarını bilmesi, Mezâlim davalarına yaklaşımı ve benzeri Me'mûn'un tebasına karşı tutumunu gösteren haberleri anlatıyor. Me'mûn'un suçluları affetmesiyle ilgili şiirlere de yer vermiştir.

Tâhir b. Hüseyin ve oğullarının haberleri başlıklı üçüncü bölüm kitabın en uzun bölümünü oluşturuyor ve üç kısma ayrılmıştır. Tâhir b. Hüseyin'in haberlerinin yer aldığı ilk kısımda onun atamalarıyla ilgili eleştirilere verdiği cevap, Tahir'in Halid b. Hammad ile sohbeti, Horasan'dan çıkışıyla ilgili konuşması, Sultanın ve ihvanın hakkı konusundaki görüşü, Şair Mihzem'e cömertliği, Me'mûn'u hilafetten hal' etmesi, Tâhir'in konuşma ve tevkileri, Yahya b. Hammad ile mektuplaşması, Tâhir' in ölümü ve oğlu Talha'nın vali atanması ile Me'mûn'un Tâhir'in ölümünü o sırada savaş halinde olan oğlu Abdullah'tan gizlemesi konularında haberler bulunmaktadır.

İkinci kısımda Abdullah b. Tâhir'in haberleri anlatılmaktadır. Onun Nasr b. Şebes'le olan mücadelesinin Nasr'ın aman istemesi, teslim alınıp Bağdat'a halifenin huzuruna gönderilmesiyle sonuçlanması anlatılıyor. İbn Tayfur, aman mektubunun tam metnine de yer vermiştir. Sonra Abdullah b. Tâhir'in Ubeydullah b. Serî ile savaşmak için Mısır'a gönderilmesi, Me'mûn'un kardeşlerinden birinin Abdullah'a iftirası üzerine onun Abbasoğullarına bağlılı̆̆ını sınamak için casus görevlendirilmesi, yenilen Ubeydullah b. Serî'nin Bağdat'a gitmek üzere yola çıkışı, Me'mûn'un İbn Tâhir'e mektubu, Vezir Ahmed b. Yusuf'un Mısır'ın fethi dolayısıyla Abdullah'ı tebrik etmesi, Tâhir b. Hüseyin ve oğlu Abdullah'ın cömertliği, Abdullah'ın meclisinde şairleri imtihan etmesi, Me'mûn'un İbn Tahir'i övmesi ve İbn Tâhir'den Me'mun dönemiyle ilgili aktarılanlarla bu kısım tamamlanmıştır.

Talha b. Tâhir'in haberlerine ayrılan üçüncü kısımda onun av yolculuğu, şairlere cömertliği, ölümü ve şairlerin ona ağıt yakmasından söz edilmiştir. 
Dördüncü bölümde anlatılan Me'mûn'un isyancılara karşı tutumu, Boran'la evlenmesi, Ahmed b. Ebû Halid'i vezir ataması konuları bölüme başlık olarak da uygun düşmektedir. Dört kısma ayrılan bölümün ilk kısmının Me' mûn döneminde İbrahim b. Aişe'nin haberleri, onun ve adamlarının öldürülmesi konusunu anlattığı görülmektedir. İbn Aişe ve adamlarının insanları Bağdat pazarlarını yakmaya kışkırtmaları, bu amaçla oraya giden köprüyü kesme girişimleri, İbn Aişe, Malik b. Şahî ve bu ikisinin adamlarının kamçıyla dövülmeleri, Mutbık zindanına atılmaları, hapishanedekileri ayaklandırmaya çalıştıkları sırada Me'mûn'un boyunlarının vurulmasını ve asılmalarını emretmesiyle bu kısım tamamlanmıştır.

Bu bölümün ikinci kısmı İbrahim b. Mehdî̀nin haberleri, Bağdat'a girdikten sonra Me'mûn'un onu yenmesi ve affetmesine ayrilmıştır. Me'mûn Horasan'dayken amcası İbrahim'in onu tanımayıp halifeliği ele geçirmesine karşı halifenin tutumu, Me'mûn'un İbrahim'in annesi Şekle'yi tehdit etmesi, İbrahim'in halifenin merhametine sığınması ve affını istemesi, daha sonra huzuruna girip şiir ve şarkı okuması, halifenin sevgili kızının ölümü üzerine İbrahim'in taziyede bulunması, İbrahim'in kendisini hicvettiği için Di'bil huzaî'nin dilinin kesilmesini istemesi, İbrahim'in evinde musiki meclisi gibi ilginç konular bu kısımda anlatılmaktadır.

Üçüncü kısım Me'mûn'un Hasan b. Sehl'in kızı Boran'la evlenmesi konusuna ayrılmıştır. Müellif, Me'mûn'un Hasan b. Sehl'in Femissılh'taki konağına ulaşması, Ninesinin Boran'ın üzerine bin inci saçması, Me'mûn'un emriyle incilerin toplanıp Boran'in odasına konması, Hasan b. Sehl'in komutanlara cömertçe verdiği hediyeler, Hasan b. Sehl'in Me'mûn ve adamları misafiriyken yaptı̆̆ı harcamaların miktarı gibi ilginç konuları anlatmaktadır.

Dördüncü kısım Ahmed b. Ebû Halid'in Me'mûn'la görüşmesi ve halifenin Fazl b. Sehl'den sonra onu vezir atamasına ayrılmıştır. Bu kısımda Me'mûn'un vezirliği Sümame b. Eşres'e teklif etmesi, onun Ahmed b. Ebû Halid'i önermesi, Ahmed'in kökeni ve bazı adetleri, yemeğe düşkünlüğü, açlık sebebiyle mektupları hatalı okuması, Me'mûn'u Ahmed'in sofrası için günde bin dirhem ayırmaya yönelten şeyler, Di'bil'in Ahmed'i oburluğu dolayısıyla hicvetmesi ve Ahmed'in cömertliğini yansıtan hikâyeler anlatılmıştır. Ahmed'in ölümü ve cenazesi haberiyle bu kısım sona ermektedir.

Beşinci bölüm Me'mûn'un âmilleriyle ilişkisi, Dımaşk'a gittikten sonra oradaki haberleri konusuna ayrılmıştır. Bölümün ilk kısmında Ahmed b. Yusuf'un Me'mûn'la görüşmesi, onun huzurundaki konuşmasını ve güzel yazı yazmasını halifenin beğenmesi, yazı ve belagatinden örnekler, Me'mûn'un cariyesi Munise ve Ahmed b. Yusuf'un ölümü konuları anlatılmaktadır. 
İkinci kısım Ebû Dülef Kasım b. İsa b. İdris'in haberlerine ayrılmıştır. Onun Yusuf ailesinin mevlası Zarif'le hikâyesi, cariyesiyle birlikte iken haberi, orada şiir söylemesi, cömertliğiyle ilgili haberler, şairlerin huzuruna girmesi, Ebû Temmâm'ın onu öven kasidesi, Abdullah b. Tâhir'in Ebû Dülef'i öven şair Ali b. Cebele'ye karşı tutumundan söz edilmiştir. Bu kısım Ebû Dülef'in Abbas b. Hasan Alevî'ye adağı ve bir şiiriyle son bulmaktadır.

Üçüncü kısımda Yahya b. Eksem'in Me'mûn'la görüşmesi ve halifenin onu vezir atamak istemesinin sebebi anlatılmaktadır. İbn Tayfur, Yahya'nın Me'mûn'la görüşmesinin sebebi, Yahya ile Sümame b. Eşres arasındaki münazara, Me'mûn'un nebiz içen kadılara karşı tavrı ile ilgili haberler aktarılmıştır. Yahya'nın Me'mûn'a öğüdü ve Abdurrahman'ın kadı olması hikâyesiyle bu kısım sona ermektedir.

Dördüncü kısımda Me'mûn'un Bizans seferi için Şam’a gidişi anlatılmıştır. Me'mûn'un sefere gidişi, gerçekleştirdiği fetihler, Me'mûn'un esirlere karşı tutumu, Bizanslı Manuel'in zulmü, Halifeyi Bizans topraklarına dönmeye yönelten şey, 20 küsur kaleyi fethetmesi ve Mısır'a gidişinden söz edilmiştir. Şam (Suriye) halkının Me'mûn'un siyasetine itirazıyla bu kısım tamamlanmaktadır.

Beşinci kısmin konusu Ali b. Hişam Mervezî'nin öldürülmesidir. Ali b. Hişam'ın öldürülmesine yol açan sebepler, öldürülmesi, başının Bağdât, Horasan, Şam, el-Cezire ve Mısır'da dolaştırıldıktan sonra denize atılması, halifenin İbn Hişam'ın akıbetiyle yakın adamlarını tehdit etmesinden söz edilmiş ve İbn Hişam'ın başına asılan rukanın metni ile konu tamamlanmıştır.

Me'mûn'un Dımaşk'taki haberleri altıncı kısmın konusunu oluşturmaktadır. Me'mûn'un Rasulullah(sav)'ın mektubuna hürmeti, hazinesindeki malın azalması, şair Ebû Nezle'nin Me'mûn'la hikâyesi, Me'mûn'un Ebû Misher Dımaşkî'yi imtihan etmesi, Muganniye Arib'i Muhammed b. Hamid ile evlendirmesi, Ebû Haşişe'nin şarkısını dinlemesi, Dımaşk kadısının azlini emretmesi, Ümeyyeoğullarına karşı tutumu konularının ele alındığı bölüm Bizans imparatorunun halife Me'mûn'a mektubu ve onun cevabiyla bitmektedir.

Altıncı bölümde Şairler ve şarkıcıların haberleri, Halku'l-Kur'an mihnesi, Me'mûn'un ve dönemindeki fakihlerin ölümü konularına yer verilmiştir. Dört kısımdan oluşmaktadır.

Birinci kısımda Me'mûn dönemindeki şairlerin haberleri anlatılmaktadır. Bu kısımda Umâre b. Akil, Halid b. Yezid, Temim b. Huzeyme arasındaki şiir münazarasından söz edilmektedir. Me'mûn'un Umâre'nin kendisini övdüğü beyitlere kafiye düşürmesi, şairlerin satranç hakkındaki görüşleri ve bunlara Me'mûn'un da katılması, halifenin Di'bil'in hicivlerine ve Ali b. Cebele'nin 
kendisini öven şiirine karşı tutumu, şairler şairini tanımaya önem vermesi bu kısmın konularındandır. Bazı şairler ve edebiyatçılar arasında münazara, Abdullah b. Tâhir'in şiire ve şairlere düşkünlüğü, Muganni Arib'in uzun bir kasidesi, Cahşaveyh'in başkadı Yahya b. Eksem'i hicveden kasidesi, bazı şairlerin Yahya'yı hicveden yirmi beyti aşkın kasidesi, şiir meclislerine katılımı dolayısıyla Me'mûn'un şiir bilgisini vurgulaması, şairlerin beyitlerine kafiye düşürmesi, güzel/iyi şiir dinlemeye düşkünlüğü, şairleri sarayında şiir meclislerine çağırması, o sıralarda Hüseyin b. Dahhak'ın, Yezidî'nin şiirine hayran kalması, İshak Mevsilî ile Attâbî arasındaki münazaraya katılması, onunla Umâre b. Akil arasında münazara düzenlemesi gibi Me'mûn dönemi edebiyat-kültür ortamını yansıtan birçok sahneye ilişkin hikâyeler bu kısımda bulunmaktadır.

Bölümün ikinci kısmında Me'mûn döneminde şarkıcıların(muganni) haberlerinden söz etmektedir. Me'mûn'un muganni Alluveyh'e cömertliği, muganni Muhârik'i terbiye etmesi, Bezl'in şarkısı eşliğinde içmesi, şarkı(gına) ve yemeğe karşı tutumu, meclisinde söyleyecek ses araması, İshak Mevsilî’ye cefa çektirdikten sonra affetmesi, Akid'in halifelik sarayındaki şarkısı, muganni Amr b. Bane'nin Hüseyin b. Dahhak'ın şiirini şarkı olarak okuması, Ahmed b. Yusuf'un mevlası Züka'nın şarkısı gibi konuyla alakalı başka haber ve özlem dolu hikâyeler bulunmaktadır.

Üçüncü kısımda müellif, bu neşeli ortamdan uzak bir konuyla ilgili haberleri aktarmaktadır: Halku'l-Kur'an mihnesi. Me'mûn'un Bağdat valisine Kur'an'ın mahlûk (yaratılmış) olması görüşü konusundaki mektubundan söz ediyor. Bu kısımda İbn Tayfur'un konuyu anlatan sonraki tarihçilerin başlıca kaynaklarından birini oluşturacak mektubun tam metnini vermesi çok önemlidir. Me'mûn Bağdat valisi İshak b. İbrahim'den fakihlerden yedi kişinin Kur'an'ın mahlûk olması görüşünü ikrar etmeleri için kendisine gönderilmesini emretmesi, Halife Me'mun bundan sonra konuyla ilgili üçüncü bir mektup daha yazması konu edilmektedir. İbn Tayfur'un bu mektubun tam metnine de bu kısımda yer verdiği görülmektedir. Halifenin konuyla ilgili görüşlerini açıkladığı üç sayfayı aşan mektubunun kendi görüşünü destekleyen Kur'an ayetleriyle süslenmiş olduğunu da belirtmemiz gerekir.

Son kısmın konusunu Me'mûn'un ölümü ile döneminde vefat eden fakihler hakkındaki bilgiler oluşturmaktadır. Me'mûn'un ölümünden söz ederken İbn Tayfur, halifenin yaşadığı son anlar, ölümünün sebepleri, defni konularına yer vermiştir. Sonra Me'mûn'un Bağdat'a geldiği tarihten ölümüne kadar olan sürede vefat eden fakihlerden söz ederek bölümü tamamlamıştır. Böylece eserin günümüze ulaşan 6 . cildinin de sonuna gelmiş olduk. 
Kitâbu Bă̆gâd'ın Tarihi Değeri| 127

\section{SONUÇ}

Eserin müellifi 819'da Bağdat'ta Babüşşam'da doğmuş 893'de öldüğünde yine aynı semtte defnedilmiştir. Horasan kökenli bir aileye mensup olan İbn Tayfur eğitimini tamamladıktan sonra önce küttübda muallimlik, sonra da sukulvarrakinde kitap istinsahı yaparak geçimini sağlamıştır. Kitap ve kültür ile iç içe olan bu ortam müellifin hem arkadaş çevresinin zenginleşmesini hem de kitaplarının malzemesini toplamasını sağlamıştır. Bütün bunlar sayesinde önemli bir kültür tarihçisi edebiyat eleştirmeni antoloji yazarı ve yazar olmuştur. Çok sayıdaki eserinden Kitabu Bă̆dad'ın 6. cildi ile Kitabu'l-mensur ve manzum adlı antoloji niteliğindeki eserinin 11, 13 ve 14. ciltleri günümüze gelmiştir. Kitabu Bă̆dad'in tek yazma nüshası British Museum'de olup ilk kez 1908'de Hans Keller tarafından yayımlanmıştır. Eserin Halife Mühtedi dönemine kadar gelen kısmını İbn Tayfur devamını ise oğlu Ubeydullah yazmıştır. Bu eserin tamamı 16 ciltten oluşmaktaydı, ancak tamamlanamamıştır. Eser Samerra Türk nüfuzu döneminde yazılmıştır. Müellif bölgesel tarihle kültürü iç içe anlatan İbn Habib Kurtubî, İbn Abdulhakem, Belazürî, Ebu Hanife Dineverî gibi öncülerinden yararlanmamıştır. Müellifin tarihi olayları kronolojik sırayla ele alan Heysem b. Adî, Halife b. Hayyat ve Taberî' den farklı bir yol izlediği görülmektedir. $\mathrm{O}$, her halifeyi tek tek anlatmış, dönemindeki siyasi olayları, atadığı görevlilerle ilişkilerini ele aldıktan sonra ilim, edebiyat, şarkı ve eğlence meclislerine yer vermiştir. Kullandı̆̆ı bu yöntem ile sakin ve ağırbaşlı üslubu ona çağdaşları arasında farklı ve ayrıcalıklı bir yer kazandırmıştır. Bağdat ve Irak'ın tarihini ilk yazan İbn Tayfur bağımsız bir tarihçidir. Plan ve anlatımından da anlaşılacağı gibi eseri özgün bir eserdir. Eserinde yararlandığı kaynaklarının çoğu şifahidir. Saraya nüfuz edemediğinden yararlandığı kâtip ve bürokratların sayısı sınırlıdır. Bilgilerinin çoğunu vezirler ve yüksek memurlar için çalışan kâtiplerden almıştır. Bunlar sayesinde kulislerin arkasına bakma şansı bulmuştur. Sonuç olarak eserinde verdiği bilgilerin kişisel gözlemlerine ve bizzat işittiklerine dayandığını söylememiz mümkündür. Ayrıca İbn Tayfur'un rivayetlerini aktaracağı raviler konusunda titiz ve seçici davrandığını, anlatacağı konu, kişi veya olaya yakın kişilerin bilgilerini öncelediğini söyleyebiliriz. Eserdeki edebi bilgiler arasında 500 beyti bulan ve bazıları doğrudan şairlerinden aktarılan şiirleri, mektup ve yazışma örneklerini sayabiliriz Eser, erken dönemde yazılmış Bağdat tarihi olması bakımından kendisinden sonra tarih yazan Taberî, Mes'udî, Ebu'l-Ferec Isfahanî ve Hatib Bağdadî gibi birçok tarihçinin kaynakları arasında yer almıştır. Taberî'nin Kitabu Bağddad'dan geniş ölçüde yararlandığı, ancak çoğu yerde müelliften söz etmediği 
anlaşılmaktadır. Kıftî'nin 309/ 921-922'ye kadar Abbasi tarihi olaylarını Taberî'den okumak gerektiğini, ancak ondan en çok yarar sağlamanın İbni Tayfur ve oğlunun eseri ile karşılaştırmakla mümkün olacağını belirtmesinden Kitabu Bağdad'ın Taberî'de bulunmayan ayrıntılı bilgiler içerdiği sonucuna varabiliriz. Son olarak eserin elimizdeki 6. Cildinin klasik bir şehir tarihinden çok, Halife Me'mun ve döneminin tarihi olduğunu söylememiz mümkündür.

\section{Ek: Râvi Listesi}

Abbas b. Hasan

Abbas b. Hasan b. Ubeydullah b. Abbas b. Ali b. Ebû Talib, Ebü'l-Fazl Alevî Abbas b. Meymun b. Tâi'

Abbas'ın kız kardeşinin oğlu Ca'fer

Abdullah b. Abbas b. Hüseyin b. Ubeydullah b. Abbas b. Ali b. Ebû Talib

Abdullah b. Ahmed b. Yusuf

Abdullah b. Amr (5)

Abdullah b. Ebû Mervan Fârisî

Abdullah b. Gassân b. Abbâd

Abdullah b. Muhammed Fârisî

Abdullah b. Rebi'

Abdullah b. Sa'îd b. Zürâre

Abdülvehhab b. Eşres

Ahbariler ve tarihçilerin bildirdiğine göre

Ahmed b. Ebû Tâhir (31),

Ahmed b. Harun

Ahmed b. İbrahim b. Davud, Ahmed b. İbrahim

Ahmed b. İshak b. Bersuma, Ebû Ca'fer Ahmed b. İshak, Ahmed b. İshak

Ahmed b. İshak b. Cerîr Mervezî

Ahmed b. İshak b. İbrahim b. Me'mûn

Ahmed b. Kâsım

Ahmed b. Kâsım İclî

Ahmed b. Muhammed

Ahmed b. Muhammed b. Abdurrahman Mühellebî

Ahmed b. Muhammed Sevabî

Ahmed b. Muhammed Yezîdî

Ahmed b. Salih Edham

Ahmed b. Yahya Ebû Ali Razî

Ahmed b. Yahya Râzî

Ahmed b. Yusuf (Kasım)

Ali b. Hasan b. Harun 
Ali b. Hüseyin (2)

Ali b. Muhammed (2)

Amr b. Bâne

Amr b. Mes'ade (4)

Amr b. Süleyman b. Bişr b. Muaviye

Arkadaşlarımızdan biri(12),

Bana bildirildiğine göre (3),

Bana haber verildiğine göre

Bana nakledildiğine göre

Bana söylendiğine göre

$\mathrm{Bu}$ rivayeti bana nakleden

Bütün tarihçiler

Ca'fer b. Muhammed Enmâtî(2)

Cerîr b. İbrahim b. Abbas

Cerîr Nasrânî

Davud b. Müsavir Abdî

Dediler ki (5)

Ebû Abbâd (Ebû Abbâd Sâbit b. Yahya b. Yesâr Râzî) (2)

Ebû Abdurrahman Semerkandî

Ebû Ali Selîtî

Ebû Bekr b. Husayn

Ebû Bekr Muhammed b. Abdullah b. Âdem b. Sabit b. Cüşem Abdî

Ebû Eyyûb Süleyman b. Ca'fer Rakkî

Ebû Hassân Ziyâdî (3), Ebû Hassan (8)

Ebû Haşîşe Muhammed b. Ali b. Ümeyye b. Amr

Ebû İshak Ahmed b. İshak

Ebû Muhammed Mutahhar b. Tâhir

Ebû Muhammed Ömer b. Muhammed b. Abdülmelik b. Ebân

Ebû Mûsâ Hârun b. Muhammed b. İsmail b. Musa Hâdî

Ebû Müslim Abdurrahman b. Hamza İbn Afîf, İbn Afîf

Ebû Talib Ca'ferî (3)

Ebû Zekeriyya Yahya b. Hasan b. Abdülhâlik, Ebû Zekeriyya Yahya b. Hasan

Ebû Zeyd Hakem b. Musa b. Hasan

Ebû'ş-Şemmâh

Ebü'l-Abbas Muhammed b. Ali b. Tâhir (5)

Ebü'l-Abbas Muhammed b. Ali b. Tâhir b. Hüseyin (2) 
Ebü'l-Atahiye

Ebü'1-Hasan (2)

Ebü'l-Hasan Ahmed b. Muhammed Mühellebî

Ebü'l-Hasan Ali b. Muhammed

Ebü'l-Hasan Musa b. Ca'fer b. Maruf

Ebü'l-Kasım Halife b. Cirve

Ebü's-Semrâ (2)

Ebü't-Tîb b. Abdullah b. Ahmed b. Yusuf

Fazl b. Abbas b. Fazl

Fazl b. Ca'fer b. Fazl

Fazl b. Muhammed Alevî, (2)

Hammâd b. İshâk

Hammâd b. İshak Mevsilî

Hâris b. Nasr Müneccim, Hâris (b. Nasr) Müneccim

Harizmî (Muhammed b. Musa Harizmî)

Harrânî (Ahmed b. Yunus Harrânî)

Harun b. Müslim

Harun b. Ubeydullah b. Meymûn

Hasan b. Abdülhâlik(2)

Hasan b. Yahya b. Abdurrahman b. Osman b. Sa'd Fihrî

Haşimî (Ebû İshak b. Süleyman Haşimî),

Hurmacı Kâsım

İbn Ebû Tâhir (3)

İbn Şebâne Mervezî, İbn Şebâne, İbn Şebane

İbrahim b. Mehdî

İbrahim b. Sindî (2)

İshak b. İbrahim Neha'̂̂

İshak b. Süleyman Hâşimî, Hâşimî

İshak Mevsilî, (5)

İsmail b. Ebû Muhammed Yezîdî

Kaderi olan Ramhürmüzî

Kahtabelerin biri

Kârî Saîd Allâf

Kâtib Ahmed b. Kâsım

Kâtib Ahmed b. Yusuf b. Kâsım

Kâtib Ebü'l-Hasan Ali b. Hüseyin

Katib Ebü'l-Hasan Ali b. Hüseyin b. Abdü'l-A'lâ

Kâtib Muhammed b. İsa b. Abdurrahman 
Kâtip Ebü'1-Kasım Abbas b. Ahmed b. Ebân

Kâtip İbrahim b. Abbas (Sûlî)

Kâtip Kasım b. Saîd, Kasım b. Saîd (3)

Kâtip Muhammed b. Abbas Sa'leb

Kelamcı Abdülaziz Mekkî Kinanî (2), Mekkî

Kusem b. Ca'fer b. Süleyman

Mansûr b. Mehdî'nin azatlısı Enyer

Me'mûn'un adamlarından biri

Me'mûn'un çocuğunun vekili Ali b. Heysem'in damadı Ebü'l-Hasan Ali b. Muhammed

Mes'ud b. İsa b. İsmail Abdî

Muhammed b. Abbâd Mühellebî

Muhammed b. Abbas

Muhammed b. Abdullah

Muhammed b. Abdullah b. Amr Belhî

Muhammed b. Abdullah b. Cüşem Rab'î

Muhammed b. Abdullah b. Tahmân (2)

Muhammed b. Ahmed b. Rezîn

Muhammed b. Ali b. Salih Serahsî

Muhammed b. Eyyub b. Ca'fer b. Süleyman

Muhammed b. Ferhân Kulzumî

Muhammed b. Hasan

Muhammed b. Hasan b. Hafs Mahramî

Muhammed b. Heysem

Muhammed b. Heysem b. Adî (2)

Muhammed b. Heysem b. Şebâne

Muhammed b. Heysem Tâî

Muhammed b. Hüseyin Vâsıtî

Muhammed b. İsa (4),

Muhammed b. İsa b. Abdurrahman

Muhammed b. İsa Hezevî

Muhammed b. İshak

Muhammed b. İshak b. İbrahim Yezîdî

Muhammed b. Musa b. İbrahim

Muhammed b. Zekeriyya b. Meymun Fergânî

Muhârik (2) 
Mus'ab b. Hasan

Musa b. Ubeydullah Temîmî (4)

Müneccim Muhammed b. Musa Hârizmî, Hârizmî

Rakkalı Ca'fer b. Muhammed Amirî

Rüzkan

Sâhibü'l-Merâkib (Gemiler sorumlusu) Muhammed b. Abdullah

Saîd b. Abdurrahman b. Mukran

Sultanın adamlarının ve ordunun ileri gelenlerinden biri

Süleyman b. Ali b. Necîh

Süleyman b. Rezîn Huzâî

Süleyman b. Yahya b. Mu'âz (2)

Sümâme b. Eşres, Sümâme (b. Eşres), Sümâme (7)

Şair Ebû Nizâr Darîr

Tağlibî (Ebû Amr (Ebû Alî) Külsûm b. Amr b. Eyyûb Attâbî Tağlibî

Tâhir b. Halid b. Nizâr Gassânî

Tâhiroğulları ailesinden biri

Tarihçiler (3)

Ubeydullah b. Abdullah b. Hasan b. Ca'fer Hasenî

Umâre b. Akîl

Utbî (Ebu Abdurrahman Muhammed b. Ubeydullah b. Amr Utbî)

Vâkidî'nin kâtibi Muhammed b. Sa'd

Yahya b. Eksem

Yahya b. Hasan (8)

Yahya b. Hasan b. Abdülhâlik (6)

Yahya Bûşencî Kasîr

Yezîdî

Zeyd b. Ali b. Hüseyin (2)

Zeyd b. Ali b. Hüseyin b. Zeyd b. Ali b. Hüseyin b. Ali b. Ebû Talib

\section{EXTENDED SUMMARY}

Within the history of Islam emergence of city and regional histories begin with Fezailü Mekke written by Hasan-1 Basri. Among the city histories written in 9th century A.C. Ibn Tayfur's Kitabu Baghdad has its own place. In this article our aim is to highlight the historical value of this book. Ibn-i Tayfur, who was born in Babussam-Baghdad in 819 AD and spent first thirteen years of his life during the Me'mun era, first worked as a teacher in the public elementary school (küttab) and then gave private lessons for the children of the wealthy families. In 850 AD he decided to gain place in Suku'l-Varrakin and make book copying. Ibn Tayfur, who 
also continued to live in Babussam in his adulthood, due to his classical education and connections he made in his Shop became a prominent cultural historian, literary critic, anthology writer and author.

Presentation of the copy and various prints of the book we have-beginning from the book including six chapters that came to our day published by Hans Keller in 1908 based on the manuscript copy of the book in British museum- is also made in this article. The writer, who was born and raised during the period of Me'mun, died in 893 A.C. after witnessing the following eight caliphs after Me'mun. Ibn Tayfur wrote the book of Kitabu Baghdad, which is also known as News and Ages of the Caliphs, till the part of Caliph Muhtedi whereas the rest of the book is written by his son Ubeydullah.

So as to understand which circumstances the book was written under, it should be noted that the book was written in Samerra Turkic influence period beginning with Caliph Mu'tasım. Samerra period, which in the beginning was a relatively stable period, towards its end, became a period where Turkic commanders and bureaucrats, with an arbitrary manner, dethroning caliphs and substituting them with ones who obey them. It is quite a misfortune that the related part of the author's book with this era, who is well known for telling the events in a realistic manner, is lost.

9th century AD is a period in which great history books were written. Authors of these books, most of which could not come to present days, had a broad vision and horizon in history. These authors, who now were free of tribal and sectarian influences, were deeming Ummah of Islam as a single state under the rule of sunni Abbasid caliph. With regard to the fact that regional history was narrated intermingled with culture by İbn Habib Kurtubi, İbn Abdulhakem, Belazuri and Ebu Hanife, these names are evaluated as predecessors of Ibn Tayfur. It is interesting that, although the last two names lived in Baghdad like İbn Tayfur in 9th century AD, they did not benefit from each other's works.

The most interesting feature of the author's method is that he followed a different path from his contemporary historians like Heysem b Adi, Halife b Hayat and Taberi who told about the events in a chronological order based on year. After telling about each of the caliph one by one İbn Tayfur transferred political events of the period, caliphs' relations with authorities he appointed and continued by telling about scientific, literacy, and music and entertainment contexts of the period. This sort of a method made him gain a matchless and distinct place amongst his contemporaries. Another distinctive feature of his style is its calm and 
dignified manner. It can be expressed that his style is mirroring the realities of the era or, with modern terms, taking a picture of the era without emotionally exploiting or stirring up. . By virtue of subjects in the part of the book we have it seems that the main goal of author is to write a cultural history. However, the fact that he did this without ignoring the political history added an extra originality and colour to his work.

His original methods and the simplicity, as well as a refined touch, in his style gives the writer a distinctive place amongst contemporary historians of his age. Ibn Tayfur is the first independent historian who wrote about history of Baghdad and Iraq which can well be understood from the originality of his book and plan. A considerable portion of his sources are verbal since he was writing in a period in which historical sources in a written format were just emerging. He benefited also of transfers from his contemporary informants as well as his own observations. Among his informants there were secretaries of high ranking bureaucrats, courtiers in the caliph's palace, his mates in evening talks and leading figures of the society following news from these sources with curiosity. As the number of clerks and bureaucrats the writer benefited from are limited it makes us think that he had only a slight influence in the palace. The writer transferred some particular information from Yahya b., who is the uncle of Fazl b Rebi. Again, it can be inferred that he gathered information from the clerks that work for high-ranking officers like Amr b. Mes'ade, Fazl b. Mervan, Ahmed b. Yusuf, Tâhir b. Hüseyin, Abdullah b. Tâhir, Muhammed b. Abdullah b. Tâhir, Hasan b. Sehl and Vâkidî. Thanks to them he was able to had the chance of taking a look on the backstage. İbn Tayfur transferred a considerable amount of information via Ali b Ubeyde Reyhan, who is both a friend and teacher for him.

News and information supplied by him seem to be closely related to the political, social and occupational positions of his informants in the caliphate capital (Darulhilafe), which indicates his precision and rigor about verifying and filtering the rumors. The fact that news about important families like Tahirids are transferred through names who are close to the family is an example of this situation.

While mirroring the entertainment life of the given era the writer relied on information about songs and singers derived from the very self of clerks, poets and singers. Among the names, whose rumors are benefited by the writer, Kâtip Ebü'lKasım Abbas b. Ahmed b. Ebân, şair Hüseyin b. Dahhâk, Muhammed b. Ali b. Tâhir, and Muhammed b. Abdullah b. Tahmân the trustworthy hadith take place. He transferred rumors of musicians like İshak Mevsilî, Allüveyh A'ser, and Amr b. Bâne as well. 
We believe that Kitâbu Baghdad is also important in sense of literary history. The book includes important texts from Arabic poetry and prose. Since various important manuscript samples from the council (divan), letters of Me'mun in the first place, are included in the book it gains importance for the sake of transfering these texts to future generations.

When it comes to the subject of poetry the fact that book includes more than 500 couplets of numerous Arab poets (90 of them) whose divans were unable to reach present, and that the writer supports nearly all topics he tells about with poems indicates how deeply the writer knows about Arab poetry of his time.

Kitâbu Baghdad, as a Baghdad and Iraq history written in early times, served as one of the prominent sources for numerous historians coming after the writer including names like Taberî, Mes'udî, Ebü'l-Ferec Isfahanî and Hatîb Bağdâdî. Taberi clearly declares that he used Kitâbu Baghdad as a source.

In this study, which indicates to what extent other historians benefited from the book Kitabu Baghdad as a source, the subjects of the parts of this work are also explained. List of the Ibn Tayfur's informants is given too as appendix at the end of the study. 


\section{KAYNAKÇA}

Brockelmann, C. (1992). İslam Ulusları ve devletleri tarihi (Çağatay, N. Çev.). Ankara: Türk Tarih Kurumu Yay.

Ezdî, Muhammed b. Yezid. (1967). Tarihu'l-Mevsıl (Habibe A. Thk.). Kahire.

Gibb, H. A. R. (1979). Tarih, İslâm ansiklopedisi (C. 11, s. 786-787). İstanbul: Millî Eğitim Bakanlığı Yay.

Gibb, H. A. R. (2017). Arap edebiyatı (Özatağ, O. Çev.). Ankara: Doğu Batı Yay.

Hatib Bağdadî (1417). Tarihu Bă̆dad ev medineti's-selâm, Beyrut: Darü'l-Kütübi'l-ilmiyye.

Hizmetli, S. (1999) İbn Ebû Tâhir, İslâm ansiklopedisi (C. 19, s. 445). İstanbul: Türkiye Diyanet Vakfı Yay.

Humeydî, Muhammed b. Ebû Nasr (1966). Cezvetü'l-muktebis. Kahire: Darü'l-misriyye.

İbnü'l-Kıftî (2005). Tarihü'l-hükemâ (Şemseddin, İ. Thk.). Beyrut.

İbn Ebu Tahir, Ebü'l-Fazl b. Tayfur Ahmed b. Tayfur Bağdadi (1949/1368), Kitâbu Bă̆dad (Hüseyni, İ. A. \& Kevseri, M. Z. Thk.). Kahire: Mektebetu Neşri's-Sekâfeti'lİslâmiyye.

İbn Abdü Rabbih (1404). Ikdu'l-ferid. Beyrut.

İbnü'l-Cevzî, Ebü'l-Ferec (1992). Muntazam fì tarihi'l-müluk ve'l-ümem, (Ata, A. Thk.), Beyrut: Daru'l-kütübi'l-ilmiyye.

İbnü'n-Nedîm Muhammed b. İshak (2019). Fihrist (Şeşen, R. Çev.). İstanbul: Türkiye Yazma Eserler Kurumu Başkanlığ Yay.

Ebü'l-Fazl b. Tayfur Ahmed b. Tayfur Bağdadi İbn Ebû Tâhir (2008). Kitâbu Bağdad=Sechster band des Kitab Bagdad (Keller, H. Deutsche der Übersetzung). Islamic Geography (159). (Sezgin, F. Ed.). Frankfurt am Main: Institut für Geschichte der ArabischIslamischen Wissenschaften an der Johann Wolfgang Goethe-Universität = Institute for the History of Arabic-Islamic Science at the Johann Wolfgang Goethte University, XXVI, 159.

Makrizî (1418). el-Hıtatü'l-makriziyye, Beyrut: Darü'l-Kütübi'l-ilmiyye.

Mantran, R. (1984). İslam'ın yayılış tarihi (Kayaoğlu, İ. Çev). Ankara. Ankara Üniversitesi İlahiyat Fakültesi Yay.

Mesudî, Ebu'l-Hasan Ali b. Hüseyin (2017). Murûc ez-zeheb (altın bozkırlar) (Batur, A. Çev.). İstanbul, Selenge Yay.

Özaydın, A. (1995). Ezdî, Muhammed b. Yezid, İslâm ansiklopedisi (C. 12, s. 48-49). İstanbul: Türkiye Diyanet Vakfı Yay.

Rosenthal, F. (1968) A history of muslim historiography. Leiden.

Sabi, Hilal b. Muhassin (1986). Rüsumu dâru'l-hilafe, (Avvad, M. Thk.). Beyrut

Sezgin, F. (2015). Arap İslam bilimleri tarihi. İstanbul: Fuat Sezgin İslam Bilim Tarihi Araştırmaları Vakfı Yay.

Şen, M. E. (2009), Selçuklu öncesi hilafet merkezinde Türk askeri varlığı, SDÜ Fen-Edebiyat Fakültesi Sosyal Bilimler Dergisi, 47, 226-232.

Tevhidî, E. H. Besâir ve zehâir, (Kadı, V. Thk.). Beyrut: Daru Sadır.

Yakut Hamevî (1993). İrşâdü'l-erib ilâ ma'rifeti'l-edîb. Beyrut.

Yakut Hamevi (1995). Mu'cemü'l-büldan. Beyrut: Daru Sadır. 